Juhan Maiste

\title{
A GENIUS AND HIS MYTH: \\ THE KNOWN AND UNKNOWN \\ MICHEL SITTOW
}

I confess that the following essay would not have been born if I had not received inspiration from Matthias Weniger's book on three Flemish artists - Michel Sittow, Felipe Morros and Juan de Flandes. These men, in the service of Isabella I of Castile, taught Spain, which had just been freed from the oppression of the Reconquista, the flamenco steps of painting, by following in the footsteps left by Jan van Eyck. Michel Sittow's story is one of a remarkable creative spirit to whom we owe the myth of one of the greatest creators of the Renaissance era and who has increasingly received attention in the last few years. And about whom I ask that I be allowed to express my opinion in this article. Max J. Friedländer rescued Sittow from oblivion; Paul Johansen assigned Sittow's work a time and a place, and reconstructed the life story of an artist that was born in Tallinn and died in Tallinn. Jāzeps Trizna, Chiyo Ishikawa and Matthias Weniger have provided frameworks for the topic. And the more different positions there are the richer science is. How much do we really know about one of the greatest creators of the Renaissance era, whose works astound us with their beauty, harmony and sophisticated complexity? What role should be assigned to the facts and what role to fantasy in the interpretation of an artist's body of work? Where does the talent of a genius begin and end and how does a myth develop? What is art history at all? Who and what do those who write about art - i.e. the art historians - represent?

DOI: http://dx.doi.org/10.12697/BJAH.2015.9.07

Translation by Juta Ristsoo. 
One can write about art in many ways. As it has been since Giorgio Vasari, who in his Le Vite de' più eccellenti pittori, scultori, e architettori gave the place of honour to the great artists of his era - from Giotto to Leonardo, Raphael to Michelangelo, collecting all the characteristic facts related to their lives and art, and placing them in a framework from which each beams back in his singularity to the present day. Others followed Vasari, including Karel van Mander and Joachim von Sandrart. Whereas art history and the writing about art north of the Alps has followed the example set south of the Alps, where the role of the artist as a genius appears as enticingly attractive as well as believable. The biographical method is undoubtedly one of the most inspired inventions of art history, allowing for facts to be assembled, selected, and compiled to fulfil our secret wish of finding a story, a narrative based on history that, like Ariadne's thread leads from the dark labyrinth of ignorance into the light, to the time and the place where the artist lived and worked.

Everything is born, lives and dies. And this is repeated time and again in some way. By bringing yesterday's facts into the present, we find ourselves in a hermeneutic circle, where speaking about art means speaking to oneself to a greater or lesser degree. A genius is an impregnator, an archetypical father figure, whose legacy needs to be remembered and kept in order, whose foreshown modes and orders (modi e ordini) are a precondition for the development of method (ragione), the purpose of which is, in turn, is to restore that which once was through the intellect's abstract principles, thereby establishing the basis for the intellectualisation of the artist's work and also the inevitable extrapolation of the creative act that was the initial basis of that work. By winning at the theoretical level, we inevitably lose in regard to lively insight. The closer art history moves to science, as it is understood within the framework of $20^{\text {th }}$ century analytical philosophy, the further away we move from art as a revelation - as a spirit that has acquired form as the prophets of aesthetic thought from Plotinus to Marsilio Ficino and Schelling have written.

Two different approaches are inherent to the elucidation of art - the intuitive and the analytical. Of these the former deals more with the world in which I - as a creator or the recipient of creation - am indistinguishable from the surrounding nature and universe and in which the metaphysical depths of cognitive recognition, which is revealed to us through contemplative concentration, is inherent, by directing the one who speaks about art away from the taxonomic methods of the rational 
brain. Both these ways of thinking are good in and of themselves. The first is associated with genius; the second leads to the myths created by and about the artist - to what the artist thought about himself and what others have said about him. The myth is what lives in post-Vasari art history, and when the myth is constructed and admired, after awhile the wish inevitably develops to disassemble it again, to deconstruct it and thereby prepare the ground for the birth of new myths.

Many geniuses probably aspired to fame. Thus, in the case of Dürer, the myth told about him by successive generations coincides to a great degree with what art historians have said about him, as described by Erwin Panofsky, whose approach coincides with the broader identity and with the "German psychology, that is marked by a curious dichotomy clearly reflected in Luther's doctrine of "Christian Liberty", as well as Kant's distinction between an 'intelligible character' which is predetermined even in a state of material freedom". ${ }^{1}$

Sittow's work, which can be positioned somewhere between the Low Countries and Germany, with some Spanish, and perhaps French traits, and as such it is so thoroughly international while also differing from it essentially, which is natural in the case of a great genius. Compared to Dürer, whose mindset and activities we are familiar with thanks to the writings he has left behind, the artist who set out from Tallinn is surrounded by a veil of mystery, which as such provides an inexhaustible resource for the birth of new interpretations. I apologise if I generalise a bit too much, but it sometimes seems that the abundant opportunities to interpret art, to group artists and systematise their work, which is a remarkable phenomenon of the art history of the Low Countries, is one reason why the period is interesting to write about. The relationships between the master and his workshop, the workshop and tradition, tradition and specific iconological and compositional patterns is a topic about which it is very difficult to draw divisions that would allow some positions to be declared true and other erroneous.

Thus, in the case of $15^{\text {th }}$ century art writing in the Low Countries, two different approaches are viable, and in this regard, I would like to cite Felix Thürlemann's words about Robert Campin: "the outstanding artists of the time were perfectly capable of producing artistically satis-

1 Erwin Panofsky, The Life and Art of Albrecht Dürer (Princeton, Oxford: Princeton University Press, 2005), 3. 
fying works with a distinct personal style even when this involved the employment of assistants." ${ }^{2}$ When writing about art, one cannot avoid dealing with the artist and his talent. And equally with the conditions surrounding him - his life and the creative circle to which he belonged. Time and again, the art historian is faced with the challenge of blending the creative work with the known facts, of speaking about the mother tree, evolution and innovation, of influences and counterinfluences, of the original, style and repetition. As J. Van der Stock asserts, Rogier van der Weyden was an artist "whose artistic inventions were frequently imitated, not only in the Low Countries but far beyond as well." 3

Therefore, how to determine an artist's bailiwick and area of activity? How to add up all his characteristic colour combinations and details: from earlobes to the toes of shoes; from eyelids to the folds in coats? While at the same time, assuming that these might differ in the case of different artists. How to compare the characteristic baselines of the works assuming that the techniques really do differ between workshops, as Dirk de Vos has written in the case of Hans Memling? ${ }^{4}$ Or should one be guided by intuition, as were Wilhelm Bode and Max Friedländer, the great names of art history from the $19^{\text {th }}$ and early $20^{\text {th }}$ century? However, is this permissible? Quo vadis art history on the threshold of the $21^{\text {st }}$ century? Who were Robert Campin or even Rogier van der Weyden really?

The present is always better than the past. The future in turn exceeds the present day. How else can we understand one of Western civilisation's main premises regarding progress, which feeds every enlightened intellect that has grown in the spirit of rational method of thought? A few years after its publication, opening Matthias Weniger's book ${ }^{5}$ about three artists that worked at the court of Isabella I of Castile, the reader is struck by surprise mixed with joy. Finally, these geniuses have entered the limelight of an authoritative art monograph and been bound between respectable covers. Moreover, one of them is a Tallinn artist,

2 Felix Thürlemann, Robert Campin. A monographic study with critical catalogue (Munich, Berlin, London, New York: Prestel, 2002), 14.

3 Jan Van de Stock, "De Rugerio Pictore. Of Rogier the Painter", Rogier van der Weyden, 14001464, Master of Passions, ed. by Lorne Campell, Jan Van der Stock (Leuven: Davidsfond; Zwolle: Waandres, 2009), 16.

4 Dirk de Vos, Hans Memling: The Complete Works (London: Thames and Hudson, 1994), $377 \mathrm{ff}$.

5 Matthias Weniger, Sittow, Morros, Juan de Flandes. Drei maler aus dem Norden am Hof Isabellas von Kastilien (Kiel: Verlag Ludwig, 2011). 
from the undersigned's viewpoint "one of our own", about whom I have expressed my opinion several times before. ${ }^{6}$

Weniger has accomplished something monumental. He has carved three great artists out of the layers of history and its patinated reception, and thanks primarily to the author's thorough presentation of the topic, the world now knows about and recognises them. This is surely one of the missions of any art historian. Typically of today's research, Weniger starts with deconstruction, thereby continuing the traditions that have developed in $20^{\text {th }}$ century linguistic philosophy, in order to arrive at each original work (the word), by eliminating everything that have been left behind by the various interpretations of culture (read: loans of language and metaphor), thereby leaving behind only a handful of primeval forms and truths, which Herder would perhaps have referred to using the prefix "ur". Weniger's question - what do we really know of Michel Sittow - is a very timely one and forces us to re-evaluate the facts. That is, what is behind the phenomenon of the world-famous artist who was born and died in Tallinn? Which shapes both his reception and myth, thereby providing an opportunity to return to the question - who was this known and unknown artist - Michel Sittow?

On the one hand, Wenger's book sits alongside the great large-format works that have been published about the $15^{\text {th }}$ century in the Low Countries, which enable art to be examined in a wider scope and more spacious geography, thereby advancing new position by destroyed old myths and constructing new ones. Instead of an undefined whole, interwoven with fantasy (art history related speculation - see Weniger about Paul Johansen ${ }^{7}$ ) such an approach invites one to deal more with the individual elements of a work, thereby freeing one from the romantic aura of a mythical hero, removing everything superfluous from the painting and, instead of a whole, provides a system comprised of single fragments, freed of the fantasy of poetic metaphor. Instead of a positive experience, we encounter negative analysis, which, as is inherent to postmodernist philosophy, does not speak about belief but rather the lack of it, just like Jacques Derrida, one of the apologists for the phenomenological philosophy, has written about negative theology.

6 Juhan Maiste, „Michel Sittow - Tallinna mees“, Eesti kunsti ajalugu 2. 1520-1770, ed. by Krista Kodres (Tallinn: Eesti Kunstiakadeemia, 2005), 15 ff.

7 Weniger, Sittow, Morros, Juan de Flandes. Drei maler aus dem Norden am Hof Isabellas von Kastilien, 39. 
The extensive exhibition called The Master of Flemalle and Rogier van der Weyden at the Städel in Frankfurt am Main and Berlin's Gemäldegalerie (Staatliche Museen zu Berlin) in 2008-2009 can be seen as an epoch-related parallel for Weniger's monograph, if not an example thereof. The exhibition gathered 60 paintings from various collections around the world and ultimately gave birth to the sceptical negation of several current beliefs, by presenting quite a radical thesis in the preface to the exhibition catalogue. "The identification of Robert Campin as the Master of Flemalle remains a matter of heated dispute even today, and scholars have been unable to establish a clear line of distinction between the oeuvre of Campin and that of his erstwhile assistant Rogier van der Weyden." ${ }^{\prime 8}$

The god of analytical art research is science and the laboratory analyses are its prophets - of course if sufficient numbers of them have been conducted to allow the works of art to be addressed not only singly and in regard to their individual particularities, but in comparison to each other and based on many individual examples. As Jochen Sander writes, "During the past forty years, moreover the results of the more modern, technological methods of examination such as X-radiography, infrared reflectography, and dendrochronology have also become important to research in this field. Yet even these have to be interpreted ... ." 9

By nature the word (image) is closed off and does not speak to its viewer in any other way than through poetic metaphor. To hear and see it, we have been given ears and eyes, that is, the same senses that, similarly to the voice, line and colour, were of help to the artist in the creation of the work. By giving science the place of honour, the art historian redeems he has left unsaid in the field of aesthetic decisions. To augment what already exists, ever newer more critical treatments appear. As we know, Rogier van der Weyden appended a signature and date to only one of his works (the first of the four Justice Panels painted for the Gulden Camere of the Brussels Town Hall). So what can we expect of the smaller stars, whose person and genius still remain anonymous today? One such artist is the Master of the St. Lucy Legend, who is also

8 Max Hollein, Berend Wolfgang Lindemann, The Master of Flémalle and Rogier van der Weyden (cat. exh. Städel Museum, Frankfurt am Main; Gemäldegalerie der Staatlichen Museen, Berlin), ed. by Stephan Kemperdick, Jochen Sander (Ostfildern: Hatje Cantz Verlag, 2009), 9.

9 Jochen Sander, "Reconstructing Artists and their Oeuvres", The Master of Flémalle and Rogier van der Weyden, 75. 
thought to be the author of the altar of the Virgin Mary in Tallinn's St. Nicholas' Church ${ }^{10}$ and who Panofsky mentions along with many other unknown masters: the master of the Catherine legend; the master of the Barbara legend; the master of the Ursula legend; and the master of the Magdalene legend. ${ }^{11}$ Unfortunately, the work of the Master of the St. Lucy Legend has remained almost unknown - and this despite his place in the published monographic surveys. And "despite 100 years of research he has not become a concept among most art historians and his name is attached to every picture of a Madonna that is not considered to be worthy of Hans Memling." ${ }^{12}$ We will come back to the St. Lucy Legend below.

As complete and rich as it is, art writing is still full of unanswered questions and contradictions that cannot be eliminated with even the most careful sifting. During the heyday of Netherlandish art, the altars produced by the workshops in Bruges and Brussels covered a territory reaching from Bruges to Toledo and from Lima to Tallinn, establishing the foundation for the development of a cosmopolitan art world, which, to use today's concepts, comprised a uniform world where the technical part of art, the techniques in use and even the pattern of images do not allow one master, or even one workshop, to be differentiated from another. This is also demonstrated by the limits of the form analysis in Weniger's book; the search for the absolute truth stumbles across a thousand details, and even critically re-reading that which has been recorded to date does not help. And this is good! Firstly, in a situation where facts are lacking, it allows the key to be found to a Pandora's Box that is lying somewhere at the bottom of the Baltic Sea or some faraway ocean. And, to set out on a new journey based on a compass needle and the coordinates entered on map. Which gives one of the most beautiful legends of Estonian art history a new shine, enabling Michel Sittow, who was born in Terra Mariana, paid his school dues in Bruges, and finally

10 For more, see: Mai Lumiste, "Lucia legendi meistri teos Tallinnas. Mustpeade altari autori probleemist", Kunst, 2 (1961), 32-42.

11 Erwin Panofsky, Die altniederländische Malerei. Ihr Ursprung und Wesen, Bd. 1 (Köln: DuMont Verlag, 2001), 350.

12 Didier Martens, "Der Brügger Meister der Lucialegende. Bilanz der Forschungen und Neue Hypothesen", Eesti kunstisidemed Madalmaadega 15.-17. sajandil. Die Kunstbeziehungen Estlands mit den Niederlanden in den 15.-17. Jahrhunderten, ed. by Tiina Abel, Anu Mänd and Reet Rast (Tallinn: Eesti Kunstimuuseum, 2000), 75. 
had an unbelievable career at the Spanish royal court and German imperial court to live on.

The more colourful its clothing, the more beautiful art history is. To see the colours one does not necessarily need a microscope (which is actually just an extension of the eye). To understand the artist, one needs to use the eye itself, which collects the artefacts into one's memory and strings them onto an Ariadne's thread, which, according to the ancient wisdom awakened by Paul Ricoueur, is called Fantasy; and which, with its unique ability to see the invisible, turns the world into imagination (Einbildungskraft), and reason (Vernunft) into ever new thought constructions. Because history speaks in two different ways - like a historian and like a poet. "Herodotus could also be put into verse, but it will remain history; whether in verse or prose, but because the historian relates what happens, the poet what might have happened"13 Thanks to Weniger, we now know what we do not know, but this should not stop us from continuing to think about what we might come to know. Sapere aude!

\section{ABOUT A MYTH. FROM BIRTH TO DEATH AND THEN REBIRTH}

When writing about art and artists, it is always important to remember who is doing the writing and when it is being done. As Matthias Weniger writes, the story of Sittow's discovery got its start in 1854, when C. F. Allen pointed out the possible link between the portrait of the Danish King Christian II and a master named Mechil, who had been invited from Tallinn to Elsinore (Helsingør). ${ }^{14}$ Paul Johansen, who discovered Sittow's Tallinn origins, started from the correspondence between Holy Roman Emperor Maximilian I and his daughter Margaret of Austria, which was published in 1839, and in which Sittow's name is mentioned. ${ }^{15}$ Later, more information was added, primarily based on Spanish sources, which, as chronologically presented by Weniger, allow the life of Isabella's court artist and, at the peak of his career, one of the queen's

13 Aristotle, On Poetry and Style, ed. and trans. by G. M. A. Grube (New York, 1987), 18.

14 Weniger, Sittow, Morros, Juan de Flandes. Drei maler aus dem Norden am Hof Isabellas von Kastilien, 14.

15 Le Glay, Correspondance de l'empereur Maximilien Ir et de Marguerite d'Autriche, 1507-1519 (Paris: J. Renouard et cie, 1839), 479, 482. See: Paul Johansen, "Meister Michel Sittow, Hofmaler der Königin Isabella von Kastilien und Bürger von Reval", Jahrbuch der Preussischen Kunstsammlungen, XLI, 1 (1940), 1. 
best paid employees to be better documented than the lives of most Netherlandish painters at that time. ${ }^{16}$

As mentioned above, the artist's Tallinn background and his specific biographical connections to his hometown were already thoroughly revealed by Paul Johansen. Unfortunately this is not true of his work in the Hanseatic town, which has roused time and again to question what has already been written, and to propose ever new hypotheses. Being critical of many of Johansen's opinions, Weniger places great faith in Anu Mänd, who has found another Michel in the archival sources to be set beside the first Michel from Tallinn. The second Michel was older than Sittow and appears in the legal documents of the day as "Michel meler" (sometimes under the distinctive name "old Michel meler"). ${ }^{17}$ Thus, A. Mänd arrives at the conclusion that there is no verifiable information about Sittow's second period in Tallinn between 1506 and $1514 . .^{18}$ There is more documentary material related to the artist's third stay in Tallinn between 1518 (1517) and his death in 1525. Based on a rereading of the documents in the Tallinn City Archives, A. Mänd states, "In 1518, from Martinmas until Christmas, he, as well as the other Michel, worked on the details of a clock set up in St. Nicholas' Church".19 In 1520, Sittow was rewarded for completing the altarpiece for the goldsmith's guild in Dorpat (Tartu), a commission that may have been intermediated by his cousin, Jacobus van der Berger, a Tartu priest. ${ }^{20}$ In 1523, he carved and gilded twelve roses for St. Mary's Chapel in St. Olaf's Church." ${ }^{21}$

Unfortunately these facts say little about the artist's creative ego. A man who was familiar with the art lovers at the royal courts of the world and about whom the words of greatest praise come from Albrecht Dürer, “... And on Friday Lady Margaret showed me all her beautiful things, and among them I saw about forty small pictures in oils, the

16 Weniger, Sittow, Morros, Juan de Flandes. Drei maler aus dem Norden am Hof Isabellas von Kastilien, 41.

17 The first to point out the name of the so-called "second Michel" was Mai Lumiste, who determined 1488-1504 to be the period when Michel meler worked in Tallinn and the Keila church. See: Eesti kunsti ajalugu 1, ed. by Boris Bernštein, Ea Jansen, Kaalu Kirme, Evi Pihlak, Vaike Tiik, Voldemar Vaga etc. (Tallinn: Kunst, 1975), 74, 95.

18 Anu Mänd, "Michel Sittow, 1469-1525", The Artist Connecting Estonia with the Southern Netherlands, ed. by. Tiina Abel (Tallinn: Eesti Kunstimuuseum, 2001), 8.

19 Ibidem, 10.

20 Johansen, „Meister Michel Sittow, Hofmaler der Königin Isabella von Kastilien und Bürger von Reval", 31 .

$21 \quad$ Ibidem, 32. 
like of which for cleanness and excellence I have never seen."22 Today, we know the names of the authors of the retablos - Juan de Flandes and Michel Sittow - to which Weniger has added the name of Felipe Morros.

"The first mention of the paintings from the Retablo was in an inventory dated February 25, 1505. Forty seven paintings 'all the same size' are described as a located in an armario - a closet or cupboard. ... Two members of the court, Alonso Xymenes and Felipe Morras, signed the inventory." ${ }^{23}$ According to the inventory ordered by Margaret in 1516, two of the panels were listed as being executed by the hand of Michel Sittow, which were separated from the others and mounted in a leather-covered diptych. These two small-scale panels $(21-22 \times 16,5 \mathrm{~cm})$ were completed between 1496 and 1502: the Ascension of Christ and Assumption of the Virgin, with a transition between the earthly and heavenly realms that is absent in most of the other paintings. The author of the remaining panels is not mentioned in the inventory.

As it has become clear from the sources, Margaret owned six other paintings by Michel Sittow, all but one of which date from his twelve years as Isabella's court painter. And which were presented by Diego Flores on 13 March 1505 as "a group including a portrait of Queen Isabella at the age of thirty and one of Margaret's sisters-in-law, Isabella (1470-1498), Queen of Portugal. A third portrait represented Margaret's comptroller. There was also a devotional painting of the Virgin with the sleeping Child, which Madame calls her favourite and a small diptych showing the Virgin Mary facing Saint and Saint John, portrayed to resemble Margaret and her first husband, Prince Juan, the only son of Fernando and Isabella." ${ }^{24}$

At this point the circle closes. Anything else we know about the artist is the fruit of the intuitive decisions of art historians, which in the case of Sittow's pictures, highlight two quite contradictory approaches: A) creative and inclusive; or B) critical and exclusive. The former got its start with Max Friedländer, who, in the early $20^{\text {th }}$ century attributed the following paintings to the almost unknown Michel Sittow: a Madonna painting from Burgos (Gemäldegalerie, Berlin); the accompanying portrait of the donor Don Diego de Guevara (?) (National Gallery of Art,

22 Chiyo Ishikawa, The Retablo de Isabel la Católica by Juan de Flandes and Michel Sittow (Turnhout: Brepols, 2004), 17.

23 Chiyo Ishikawa, The Retablo de Isabel la Católica by Juan de Flandes and Michel Sittow, 5-8.

24 Ibidem, 13. 
Washington D.C.); and the portrait of a beautiful lady (Catherine of Aragon in the Art History Museum in Vienna. ${ }^{25}$ Although the last of them has been renamed later as Mary Rose Tudor, sister of Henry VIII of England ${ }^{26}$ or Joanna of Castile (Juan la loca) ${ }^{27}$ or then Isabella I herself ${ }^{28}$, what we can distinguish are the charming facial lines as characteristic to Sittow's genius.

Starting with Friedländer, the number of art works connected to the Sittow name started to increase, thereby providing Jāzeps Trizna, who wrote a monograph about the artist in 1976, an opportunity to divide the artist's work into four groups based on the following argumentation hierarchy: "Oeuvres documentées encore existantes (3 works), oeuvres documentées disparues (10 works), attributions certaines (6 works) and attributions douteuses (13 works). The last and fifth category is comprised of attributions that Trizna believes are untenable, and is the largest category, i.e. totalling 25 works." ${ }^{29}$ To a great extent, Weniger repeats these assessments, and in the book's catalogue, divides the material into the works that can be attributed to Sittow (13) and the works that can be not attributed to him (Sittow nicht entscheidbare Fälle und potentielle Nachfolgerwerke; a total of 111). By highlighting the best of the works from among those that have been sifted out, this approach undoubtedly provides new opportunities for assessing and analysing Sittow's body of work within the era's painting tradition and against the background thereof.

At the same time, the list presented by Weniger does not preclude intrigues - and this despite the following warning by the author, presented at the beginning of the book: "Die falschen Zuschreibungen übertreffen die Zahl der eigenhändigen Werke um mehr als das Zehnfache."30 The artist who departed from Tallinn is one of a congregation of Flemish artists, "for whom it was by no means unusual to settle in foreign cities or to offer

25 Max J. Friedländer, "Ein neu erworbenes Madonnenbild im Kaiser-Friedrich-Museum", Amtliche Berichte aus den Königlichen Kunstsammlungen, XXXVI, 9 (1915), 177-178.

26 At the exhibiton „Van Eyck to Dürer. Early Netherlandish Painting. Central Europe 1430-1530“, Groeningemuseum, Bruges (29.10.2010-30.01.2011).

27 Elisa Bermejo, „Pintura de la època de Isabel la Católica“, Isabel la Católica. Reina de Castilla, ed. by Pedro Navascués Palacio (Barcelona, Madrid: Lunwerg Editories, 2002), 146.

28 Weniger, Sittow, Morros, Juan de Flandes. Drei maler aus dem Norden am Hof Isabellas von Kastilien, 77.

29 Jazeps Trizna, Michel Sittow, peintre revalais de I'ecole brugeoise (1468-1525/26) (Brussels: Centre Nacional de Recherches Primitifs Flamands, 1976), $91 \mathrm{ff}$.

30 Weniger, Sittow, Morros, Juan de Flandes. Drei maler aus dem Norden am Hof Isabellas von Kastilien, 12. 
their services to a variety of princely courts". ${ }^{31}$ Who brought with them various impulses and customs, creating as Weniger writes, "Summa des in anderen Werkstätten und bei anderen Künstlern gesehen". ${ }^{32}$ During his youth, Sittow completed an inspirational school, which undoubtedly based in the Low Countries and is supported by the chivalrous Burgundian germ by providing new, as well as a deeper and more humane, content against the background of a humanist-era spirit. Having started with Jan van Eyck, it was followed by Hugo van der Goes, whom Weniger has proposed as the one that possibly had the greatest influence on Sittow. ${ }^{33}$

"The man from Reval measured himself against the greatest. As a cultural ambassador, he absorbed ars nova, aligned it with his own background and made sure his pictorial ideas became widely spread." ${ }^{34}$ Sittow's world is as wide as it is narrow. Until the facts prove otherwise, I will maintain the position that Sittow is linked to Memling by more than just an era-based similarity. Having come from the Germanspeaking cultural space, they are both characterised by an ability to delve into something's nature and its individual details to get closer to the spiritual inner world of the subject, where under the surface sub-currents are moving with the waves caused by the following winds and simultaneous lateral waves. And all these combine to add that special mystical contemplative dimension to an artist's work, which, starting with Panofsky, has been emphasised in the case of Albrecht Dürer. ${ }^{35}$ Although the works attributed to Sittow and the works by Dürer sprung from different ground, these two represent the absolutely highest level of this world, which as such enchants. Let's recall that it was Dürer who, through the mediation of Margaret of Austria, painted a portrait of the Danish King Christian II, seven years after Sittow had done so. ${ }^{36}$

31 Till-Holger Borchert, "The Mobility of Artist. Aspects of Cultural Transfer in Renaissance Europe", The Age of Van Eyck. The Mediterranean World and Early Netherlandish Painting: 1430-1530, ed. by Till-Holger Borchert (New York: Thames and Hudson, 2002), 33.

32 Weniger, Sittow, Morros, Juan de Flandes. Drei maler aus dem Norden am Hof Isabellas von Kastilien, 19.

33 Weniger, Sittow, Morros, Juan de Flandes. Drei maler aus dem Norden am Hof Isabellas von Kastilien, 65.

34 Matthias Depoorter, Van Eyck to Dürer (Bruges: Lannoo, 2010), 30.

35 Panofsky, The Life and Art of Albrecht Dürer, $3 \mathrm{ff}$.

36 For more, see: Else Kai Sass, "A la recherche d'un portrait disparu de Christian II, Roi de Danemark, peint par Albrecht Dürer en 1521", Hafnia: Copenhagen Papers in the History of Art, 4 (1976), $163 \mathrm{ff}$. 


\section{SITTOW LEAVES HOME}

When looking at Sittow's pictures, the nobility, elegance, and a certain refined esprit characteristic of the world's most splendid courts exudes from them, along with an inner conviction and peace that has grown out of his domestic conditions, a world that Sittow knew well and to which he returned time and again. Sittow's pictures are characterised by a reverent peace and a spiritual admiration for the divine and higher power, which sometimes seems even to exceed the religious experience typical of Bruges art and its imagological and iconological frameworks. What has to date gone unnoticed or been noticed insufficiently is the particularity of Sittow's religious-themed compositions, which add a Spanish-style note to Jan van Eyck's apocalyptic mood, making itself apparent in the form of a melancholy adagio, which, along with the physical, highlights the metaphysical and places a dark tone next to the bright one. Thereby producing a mystical longing for a religious experience, a tender and contemplative mood, which characterises Sittow's art and, along with his technical mastery, enables his work to be distinguished from that of his contemporaries.

Michel left his hometown in 1484, when he was 16 or 17 years old and, based on the understandings of the day, was no longer a very young man, and certainly not a boy, who could not decide where he should go. Having been educated at the Dominicans' convent school in Tallinn, where his uncle, Dominicus Sitau, was lector theologiae, and his teacher in the field of art was his father, Clawes van der Sittow, who Johansen believes, had Flemish blood flowing in his veins. Thus Sittow did not set out with empty hands or as a tabula rasa. Quite the opposite, considering his family's position and Tallinn's place as a Hanseatic town on the commercial and cultural map of the day, we are not dealing with a humble supplicant on a grand Western threshold, but a man who, as a citizen of Tallinn, had property and the courage to knock on the most important doors. Obviously, Michel has seen the large altars in Tallinn's great churches, was present when, on The Coronation of Mary Day, 18 May 1483, Bernt Notke installed the altar in the Church of the Holy Spirit that the city council has commissioned from him, and met the master 
and his assistants (whoever they were). It is not impossible that Sittow as a young man might have seen also Notke's Dance of Death in Tallinn. ${ }^{37}$

In some sense, the master, who we know as the painter Notke, and Michel Sittow had drunk from the same well. Yet the myth of Notke and the myth we connect with Sittow are different. ${ }^{38}$ Instead of the expressive attitude and religious exaltation characteristic of Rogier van der Weyden - whether in regard to Mary Magdalene on the Triumphal Cross in Lübeck Cathedral or the empress on the Dance of Death cycle in Tallinn - in Sittow's case we encounter a subtle palette typical of Jan van Eyck and a glorification of beauty in its sincerely sublime form. Thereby, in addition to the extraneous note described as the main character of Nordic art at the turn of $15^{\text {th }}$ and $16^{\text {th }}$ centuries $^{39}$, a classical clarity based on classical art (Italian examples - Antonella da Messina, etc.) is brought to the fore. The treatment of light and shade typical of the artist in his maturity, a certain fateful line in his portraits provide an opportunity not to limit the treatment of Sittow's work to the aesthetic circle of Netherlandish art. The artist's transparent compositions are oriented to the unreal along with the real, which, along with the iconological plane, reveals itself in the metaphysically mysterious colours, a certain apocalyptic light that characterises the artist's religious compositions ${ }^{40}$,

37 Researches have not reached a consensus regarding the time the Dance of Death was completed, its original location (building), or the issue of authorship. The dates ranged from 1463 as proposed by Carl Georg Heise (indicated on the Lübeck original) and extended to the early $17^{\text {th }}$ century, as suggested by Friedrich Amelung; the earlier completion time, more precisely the 1460s or 1470s suggested in his polemic work Wahrheit und Mythos Peter Tångeberg (based on similarities with the Flemish art of the same decades), Kerstin Petermann dated it from the 1470s or 1480s (based on a stylistic comparison with the other works attributed to Notke). No less important date is presented by Mai Lumiste based on direct (on the architecture and autumn landscape along with the genre scenes that were revealed in the course of the restauration) and indirect argumentation (on presumed location in the St. Anthony's Chapel of St. Nicholas' Church and on Notke's authorship), Lumiste determined that Tallinn's fragment was completed at the end of the $15^{\text {th }}$ century or beginning of the $16^{\text {th }}$ century. About further discussion see: Krista Andreson, „Research on Tallinn's Dance of Death and Mai Lumiste Questions and Possibilities in the 20th Century“, Kunstiteadsulikke Uurimusi, 22 (3-4) (2013), 96-109. 38 The works attributed to Notke differed greatly in terms of form, style and quality, and this, in turn, indicated the existence of large and mobile workshop (Kerstin Petermann, Bernt Notke. Arbeitsweise und Werkstattorganisation im späten Mittelalter (Berlin: Reimer, 2000)) or lead us back to Wölflin's "Kunstgeschichte ohne Nahmen” (Martin Wangsgaard Jürgensen, „Do we need Bernt Notke? Some reflections on workshops and masters", Art, Cult and Patronage. Die Visuelle Kultur im Ostseeraum zur Zeit Bernt Notkes, ed. by. Anu Mänd, Uwe Albrecht (Kiel: Ludwig, 2013), 15).

39 Andrew Morall, „Defining the Beautiful in Early Renaissance Germany“, Concepts of Beauty in Renaissance Art, ed. by. Francis Ames-Lewis, Mary Rogers (Aldershot, Brookfield, Vt: Ashgate, 1998), 80-92.

40 By considering the colours we have to take into the consideration the hange of tonality and the patina problems. 
and that something special, a longing that cannot be put into words that gives the artist's portraits their unique appearance - a finely crafted mastery on one hand and filled with emotion on the other - the message of which can be interpreted in the context of both psychological realism and philosophical contemplation, which reaches further and higher than the former and in which, according to the Neo-Platonic teaching popular at the time, angels move as earthly hypostases.

Beside Tallinn and its religious atmosphere Sittow's spiritual ego grew in the frames of his experience in broader world, about what the artist himself has said: "I was out of the country because I wished to learn my trade and art ... and in Bruges, in Flanders I had to pay six Flemish pounds a year for my keep to learn my trade. ${ }^{\prime \prime 1}$ The natural choice of the young man was Memling, who by this time could claim to be the greatest living painter in the Low Countries alongside Hugo van der Goes in Ghent and Petrus Christus", and of whom the latter two had already departed this world (Dierick Bouts died in 1475-76; Hugo van der Goes in 1482). ${ }^{42}$ Of the great names, Memling was the only one to turn to. As Dirk de Vos says, "Who other than Memling - who himself had very little to do with the painter's guild, and who evidently had contacts in the most influential circles - could have been the teacher of this talented young artist? Michel Sittow must have continued to work for Memling as journeyman for four years after having completed his apprenticeship. This is suggested by the similarly refined brushwork of the two small surviving works" (the author is referring to the Don Diego de Guevera diptych). According to De Vos, Sittow was "the principal assistant who helped Memling achieve his enormous output in the late 1480s", and adds this summarising opinion: "Sittow's contribution to Memling's paintings is, however, as impossible to unravel as is Memling's own input in the oeuvre of Rogier van der Weyden." ${ }^{\prime \prime 3}$

41 “ $i k$ was buten landes vmme lere willen myner kunst vnde amptes, do ... myne zalige moder vorlauet wart, vnde ik moste bynnen Brugge in Flanden alle iar geuen vor myne kost to iszliken iar 6 punt grote sunder myne cledynge etc." About which his stepfather said in the Lübeck court: " ... heft oens oeck veel bueten laendes gekoest ... 200 marck." See: Paul Johansen, "Meister Michel Sittow, Hofmaler der Königin Isabella von Kastilien und Bürger von Reval”, 10.

42 De Vos, Hans Memling: The Complete Works, 36-37.

43 De Vos, Hans Memling: The Complete Works, 46. 
As mentioned above, before his arrival in Spain, no documentary fulcrums are provided by Sittow's biography. Johansen's thought flies from Flanders to France, which at the end of the Hundred Years' War in the $15^{\text {th }}$ century, had awoken from a bewitched sleep and provided extensive employment opportunities for its own artists and those from the Low Countries; who, together with the revived French art, brought with them a trend that has been defined as "the Gothic in the Renaissance". ${ }^{44}$ And which, in its deeper essence preserved a link with the transcendental along with the immanent, thus making a contribution to the supernatural along with the natural, as can also be seen in the German art of the late $15^{\text {th }}$ and $16^{\text {th }}$ centuries. When reading Johansen, one's thoughts travel even further. Margaret of Austria lived in France starting in 1482, where she lived at the court of Louis XI and after his death was raised as a fille de France under the supervision of her fiancé's (Charles VII's) sister and regent Anne de France. However in the autumn of 1491, Charles married Margaret's stepmother Anne Duchess of Brittany, for political reasons. The French court had ceased treating Margaret as queen early in 1491.

Johansen has put Sittow living in the entourage of Margaret in France until 1492. ${ }^{45}$ Several other Sittow researchers have also alluded to the French theme. Thus Jacques Foucart says in the impressive catalogue of Spanish-Flemish art in 2003 that heightened religiosity is typical of his painting, and also alludes to the possibility that between the years 1489-90 and 1492, prior to his arrival in Spain, Sittow spent some years in France. The author also compares Sittow's early works to those produced by Flemish artists who worked in France during the same period, among them Jean Hay, alias the Master of Moulins, 1480-90, who was an attentive disciple of Van der Goes. ${ }^{46}$

But there are several differences between Sittow and the other artists working in Spain at that time. In his Coronation of the Virgin (Louvre, Paris), the Holy Father is depicted with a bushy beard, one can recognize the motifs of Hermen Rode and Bernt Notke. The angel figures used by

44 Henri Zerner, Renaissance Art in France. The Invention of Classicism (Paris: Flammarion, 2003), $11 \mathrm{ff}$.

45 Johansen, "Meister Michel Sittow, Hofmaler der Königin Isabella von Kastilien und Bürger von Reval", 13.

46 Jacques Foucart, Michel Sittow, La pintura gótica hispanoflamenca. Bartolomé Bermejo y su época (Patronat del Museu Nacional d Art de Catalunya, 2003), 581. 
the artist are common in many pattern books of the time. Whereas in Sittow's case, personality traits can be pointed out that only characterise his genius. As Foucart writes: "Sittow seems to have been the only painter to adopt such a bold formula, which enables him to introduce, on the formal plane, a charming ballet of graceful winged figures, thereby breaking with the usual presentation, sensibly formal and hierarchical, of the Coronation with the Virgin Mary seen from the front in the centre of the composition, framed by the three figures of the Trinity still common in the case of Memling. ... The present diagonal disposition favours the deeper rendering of space, giving the impression of infinity, despite - or perhaps as a result of - the abstraction of a heavenly firmament. The traditional frame of cloud is present, though subtle, tending to imagine and preserve a sort of circular, floating other world, isolating and idolising an extraordinary hierophanty, what man has never seen." ${ }^{\prime \prime 7}$

One of Sittow's possible sources of inspiration could be Nicolas Froment (1435-ca.1486), who, as a representative of the École d'Avignon, produced many altar compositions, including the large Triptych of Moses and the Burning Bush, which was commissioned in 1476 by René, the last Count of Provence, for the Carmelite convent in Aix en Provence (today in the Cathedral of the Holy Saviour). On the closed outer wings of the altar we find a scene of the Annunciation - the Angel Gabriel and the Virgin Mary with a book, who has stopped reading the Scripture upon listening the angel's salutation. The donor of the altar was René I of Naples known as Good King René (French Le bon roi René), Duke of Anjou, Count of Provence, Count of Piedmont, Duke of Bar, Duke of Lorraine (1431-1453), King of Naples and titular King of Jerusalem and Aragon (including Sicily, Majorca, Corsica). He is dressed as a canon of Saint Victor, with his prayer book in front of him and his crown on a tapestry displaying the arms of Sicily.

By all said, it is worth to be mentioned that Saint Victor was also known and popular in Tallinn. Depicted on three altarpieces that have survived to the present day: Hermen Rode's main altar in St. Nicholas' Church (1478-1481); Bernt Notke's altar in the Church of the Holy Spirit (1483); and the altar of the Virgin Mary, and that can be pointed out as

47 Jacques Foucart, Michel Sittow, La pintura gótica hispanoflamenca. Bartolomé Bermejo y su época, 581. 
an exception. According to A. Mänd, St. Victor of Marseille's cult was little known in Northern Europe. ${ }^{48}$

Anu Mänd has also found other examples of Victor's popularity - be it St. Victor of Marseille or Xanten - which are associated with the Great Guild or the Confraternity of Black Heads, which have allowed her to come to the conclusion that the cults of these two - the Victor that was executed in Xanten as well as the Victor who suffered a martyr's death in Marseille have been blended together in the far away Hansa city. There was a St. Victor's Guild in the town, what has given A. Mänd the confidence to propose quite a daring hypothesis about St. Victor being the patron saint of the town counci ${ }^{49}$ and playing a noteworthy role along with two other warrior saints - St. Mauritius and St. George.

Victor's burial place in Marseille had been one of the most important places of pilgrimage since the time of Gaul. But for some reasons he was not well-known in Germany. However, in the Low Countries the cult of St. Victor can be found in different eras. For example "the township of Mechelen possesses seventeen panels from 1510-1520 about St. Victor's life, presumably originally the designer for the chapel of the Mechelen convent for Victorian nuns." ${ }^{\prime 50}$ Altar compositions with a large number of small panels, similar to Isabella's retablo, were also produced in many other workshops, for instance, the series on St. Rochus painted by Valentin or Evard van Orley for Antwerp's St. Jacobskerk. According to Catheline Périer-d'Ieteren, the 25 altar panels in St. Rumbold's Cathedral in Mechelen come from at least three different workshops ${ }^{51}$, the majority are local works, and one panel depicting the legend of Magdalene has been attributed to a Brussels Master. Some years later, the same artist painted the portrait of Margaret of Austria at the Court of Savoy in Mechelen (now in the Louvre).

These are some parallels, which provide an opportunity to establish Tallinn in the Netherlandish cultural room in the circumstances where a unique "Flemish polyphony", which was initially associated with miniature painting, and with the development of printing techniques spread far beyond the French-Burgundian workshops, being of vital

48 Anu Mänd, "Püha Viktor - Tallinna kaitsepühak", Kunstiteaduslikke Uurimusi, 12 (3-4) (2003), 9 ff.

49 Ibidem, $24 \mathrm{ff}$.

50 Bert Verriest, De legende en de Mirakelen van Sint-Rombout in de Sint-Romboutskathedraal te Mechelen (Regensburg: Verlag Schnell und Steiner, 2000), $6 \mathrm{ff}$.

51 Catheline Périer-d'Ieteren, „Deux panneaux de la Légende de Saint Rombaut de Malines, conservés à Dublin“, Jaarboek van het Koninklijk Museum voor Schone Kunsten Antwerpen, 1976, 83 ff. 
importance to the transmission of images to enrich an artist's or workshop's repertoire of motifs and patterns. ${ }^{52}$ As copying was also meant to train the eye and hand. ${ }^{453}$ The images and themes familiar to Sittow in his later career, were common and even well known to him already from the times he spent in Tallinn as a child.

\section{RELIGIOUS COMPOSITIONS}

The cornerstone for all the Sittowiana to date is an armoire (Schrank) opened by Isabella's successors on 26 February 1504 in which "47 'gleiche' Täfelchen, die Ereignisse aus der Kindheits -, Leidens- und Auferstehungsgeschichte Christi sowie die Erzengel Michael und Gabriel bzw. Die Apostel Johannes und Jacobus wiedergaben." ${ }^{54}$ As Chiyo Ishikawa writes, "due to the unfinished state and early dispersal state", the panels of the small personal home altar that belonged to Isabella were almost unknown until the $19^{\text {th }}$ century ${ }^{55}$ Today they are a confirmation of Sittow's world, where, in 1492, the religious element under the name "melhior Alemann pyntor" entered the service of Isabella I of Castile, and where the artist, who earned the fifth largest salary, was known for his religious compositions and portraits. ${ }^{56}$

The undersigned believes that these two genres - religious paintings and portraits - form the axes of Sittow's art, representing two thematically different approaches that also differed when it came to the artist's individual style. The ideological sources thereof lead us, on the one hand, to the contradictory sacral spirit - partly reaching back to the Middle Ages and partly open to innovation - and on the other, to humanist ideas, which had been maturing for a century or more. Already in 1447 the artist's uncle Dominicus Sitau invited Dr. Albertis Petri, the "congregatio Hollandie" to Tallinn to preach about the early reformatory ideas. The monks who accompanied him were housed in Michel's father's house. As Johansen has stated, that was Dominicus who arranged for the new

52 Miniatures flamandes 1404-1482, ed. by. Bernard Bousmanne and Thierry Delcourt (Bibliothèque nationale de France/Bibliothéque royale de Belgique, 2011), $166 \mathrm{ff}$.

53 Guido Messling, "Drawing in Germany from van Eyck to Dürer", The Age of Van Eyck. The Mediterranean World and Early Netherlandish Painting: 1430-1530, 97.

54 Weniger, Sittow, Morros, Juan de Flandes. Drei maler aus dem Norden am Hof Isabellas von Kastilien, 25.

55 Chiyo Ishikawa, The Retablo de Isabel la Católica by Juan de Flanders and Michel Sittow, 1.

56 Weniger, Sittow, Morros, Juan de Flandes. Drei maler aus dem Norden am Hof Isabellas von Kastilien, 40. 
altar of the Virgin Mary to be installed in the monastery's St. Catherine's Church of the Dominican monastery. ${ }^{57}$

Spain received Sittow during a tidal wave of new religious awakening, which provided Catholicism, which was toughened by the fight against Islam, with a political mission and gathered an influential company of church fathers around Isabella. Spain became the home of the man who had left Tallinn, and at the same time, as is sometimes asserted, his spiritual cloister. Michel's palette darkens, acquires a placidly pallid, not to say ghostly, appearance of the Spanish "sociego", which, under the influence of two scholars from the University of Salamanca - Pedro Gonzales de Mendoza and Hernando de Talavera - has garnered favour in the literature and art of the period. Compared to Memling, Sittow's colours are darker, and in his religious compositions, depart from the golden circle of $15^{\text {th }}$ century Flemish art. And replace its metaphysical revelation with the melancholic adagio typical of the artists gathered around Isabella, adding special shading to the flamenco rhythm that is characteristic only of the Iberian Peninsula. In Castile, the style of Sittow achieved a new credibility. "Spirtualis sub metaphoris corporalium." 58 The spiritual is corporeal and vice versa; something that "enjoyed the total predilection of Isabella, and revealed the sensibility and refinement of her artistic tastes." ${ }^{\prime 59}$ Sittow's predecessors include both the Master of Flemalle (The Virgin in Glory of with Donor and Saints Peter and Augustine, Museé de Beaux Arts, Aix-en-Provence ${ }^{60}$, as well as many later works by Rogier van der Weyden and Hans Memling. The same elements repeat from painting to painting - a haloed sun, rainbow as the supporting arch for the heavens, God the Father, Christ and the Virgin Mary in a golden aureole on the highest steps of the heavenly hierarchy. These same elements predominated in the large cathedrals during the prayers at low Mass and large-scale mysteries.

All three of Sittow's small-format paintings - the Ascension of Christ, Assumption of the Virgin and Coronation of the Virgin (although the latter differs in format from the first two) - are borne by one and the same idea,

57 Johansen, "Meister Michel Sittow, Hofmaler der Königin Isabella von Kastilien und Bürger von Reval“, 9.

58 Panofsky, Die altniederländische Malerei. Ihr Ursprung und Wesen, 119.

59 Elisa Bermejo, "Painting in the Period of Isabella the Catholic", Isabella, The Catholic Queen of Castile, ed. by Pedro Navasucés Palacio (Barcelona: Lunwerg, 2002), 18.

60 Also attributed to Robert Campin and Rogier van der Weyden. See: Till-Holger Borchert, "The Mobility of Artists. Aspects of Cultural Transfer in Renaissance Europe", 38. 
to depict what is invisible to the naked eye and which becomes comprehensible, when the third eye - the "window to the soul" - is opened, as Marsilio Ficino has written, thereby making the invisible visible, in which case the past means the present and the present lives along the future and they all become visible in nowhere else than just in one's own imagination. His frail kneeling virgin on the painting called Coronation of the Virgin recalls the chorales of Guillaume Dufay, the form of which is related to the logic of sacred numbers, and the soul however, to mystical contemplation, giving Sittow's art a special quality.

The beguilingly graceful surface hides the higher goals of Christian mission, which have developed during the Spanish royal court's battle with fundamentalist Judaism and hedonist Islam, and which led Isabella to root out heresy. The golden yellow sky on the Assumption of the Virgin Mary is deeper than we are used to seeing on compositions by Memling or those born as illustrations in Gerard David's St. John's Book of Revelations. The angels floating in the violet light under Mary's feet holding an upside-down crescent; the sky that has become pitch black in places (which, it's true, may be partly related to the patination of the painting's surface). Biblical cities appear from the buoyant clouds in the distance as seen on the many visionary scenes of the early $15^{\text {th }}$ century.

Sittow is a part of his time and era; his religious devotion belongs to a tradition, the exalted thematic approaches of which are revealed in the form of the apocalyptic skies and revelational scenes of German and Netherlandish art. And it thereby presages the disappearance of the old life and arrival of the new, as had been depicted in the miniature painting from the late $14^{\text {th }}$ century and which lived on in the religious compositions of the so-called "Master of Frankfurt", whose choice of subject matter for his Altarpiece of St. Anne, alludes to both the Legenda aurea and the interpretations thereof by Petrus Christus and Rogier van der Weyden. ${ }^{6}$

The iconological sources of Sittow's religious art are similar to the Netherlandish and German masters of the late $15^{\text {th }}$ century (for instance, the Master of the Joseph Sequence) and are achieved "with the use of

61 Jochen Sander, „Das Annenretabel des Meisters von Frankfurt im historischen Museum Frankfurt“, Der Annenaltar des Meisters von Frankfurt, ed. by. Wolfgang P. Cilleßen (Frankfurt am Main: Henrich Editionen, 2011), 12, 36. 
different stereotypes and craftsmanship", 62 that appeared in the works of many masters who have remained anonymous ${ }^{63}$, the finally reading of which, to a great extent, still lies before us. One of the most intriguing themes, to re-examine in the future, is Christ Bearing the Cross (The Pushkin State Museum of Fine Arts in Moscow), which, starting with Johansen, has been attributed to Sittow, and is famous for the numerous copies and parallels that together speak of the era in which Sittow worked. ${ }^{64}$

And yet, Sittow is a genius of his own spirit and pictorial world. The heavenly Gloria appears on Sittow's paintings in metaphysically sublime light, with a silver halo around her head, with radiating golden beams that cast her as the "woman clothed by the sun" with a crown of twelve stars upon the head. The other figures in the painting are also not standing on a solid surface or even a rainbow, but are hanging nebulously between earth and sky, thereby opening the gate to the art that was cultivated by Diego de Cruz and Pedro Berruguete, and which was brought to culmination by El Greco a half century later.

\section{PORTRAITS}

Considering the portraiture of the era, Sittow occupies an exceptionally high place, providing an opportunity for his heroes to be seen as dreamily distant and also intimately close, and thereby indicating the artist in the circle of Hans Memling, whose portraits, such as the portrait of Tommaso Portinari, are miracles of naturalistic observation and painterly virtuosity: with the subtly nuanced flesh tones. ${ }^{65}$ In Sittow's work, a refined striving for taste and perfection is associated with highlighting the introverted life of the characters, and makes his portraits distant

62 The Flemish Primitives, IV. Masters with Provisional Names (cat. of Royal Museums of Fine Arts of Belgium), ed. by. Pascale Syfer - d'Olne, Roel Slachmuylders, Anne Dubois, Bart Fransen, Francke Peters (Turnhout: Brepols, 2006), 64.

63 For example, the Virgin Mary with the Infant Jesus from the tryptch by the Madonna master (Aert van der Bossche) in the Grog Collection. Exhibited at the Tallinn Town Hall in 2015 at an exhibition of early Netherlandish and German art. See: Kunst valitseb maailma, Meistriteoseid 15.-17. sajandist. Valik erakollektsioonidest (Tallinn: Art-Life Projekt, 2015), 40.

64 A few paintings with similar approaches could be seen at an exhibition of early Netherlandish and German art at the Tallinn Town Hall in 2015 (Christ Bearing the Cross, Cornelis Engeldrechtsz, Leiden 1468-1525; Christ Bearing the Cross, anonymous master, 1515).

65 Paula Nutall, "Memling and the European Renaissance Portrait", Memling and the Art of Portraiture, ed. by Till-Holger Borchert (London: Thames and Hudson, 2005), 73-74. 
and unapproachable, granting the portraits of rulers a place on the era's elitist Parnassus. In Sittow's depiction of Mary we recognise the tradition that developed based on the example of the Mater Dei, the roots of which date back to the $14^{\text {th }}$ century and which lived on in Memling's art under the name of Notre Dame de Grace (cf. The Virgin and Child, The National Gallery, London; the Madonna on the Shrine of St. Ursula reliquary, Saint John's Hospital, Bruges) and, as such, are also familiar from the art of Hugo van der Goes, Dierick Bouts and many minor masters.

Sittow's palette is extremely nuanced. Mary's gentle and femininely appealing face emerges from the dark background like a beautiful apparition, which is accentuated by the luminous skin in the beam of light falling on her forehead. In the artist's painting, this delightful moment of silence is associated with thoughtful meditation, and brings forth a spiritual experience inherent of a sacra concersazione. Mary's eyelids are lowered; her femininely and delicately closed mouth and golden curls falling from underneath her cap speak in a way that observes the techniques borrowed from Memling, but are more nuanced, flexible, deeper and oriented toward inner harmony. One can even ask - has Sittow portrayed one and the same woman - a wistful conception of Isabella I of Castile, whom we know from the many portraits made of the queen? Or does a specific ideal live in Sittow's imagination, who, like Beatrice or Laura, steps forward in the artist's recollection or fantasy.

In comparison to the female portraits the male portraits by Sittow have a more severe look, which in their concrete reality depict mostly of high state officials, rich and insightful merchants; in any case, people whose position, dignity and inherent charisma provide a reason to delve deeper into the various nuances of the subject's character, motivating one to reconsider, and initiate a mental conversation with the persons portrayed. On the one hand, Sittow's portraits are a continuation of Rober Campin's and Rogier van der Weyden's work, in which the individual's unique character and dignity is highlighted. From the other side the artist has gone further. As a sharp-eyed observer, he is capable to expose the various layers of the human soul, what makes possible to compare him with his famous contemporary, Albrecht Dürer.

Most of Sittow's known portraits were completed when he was a mature man - the Danish king Chritian II or Don Diego de Guevara, a knight of the Spanish Order of Calatrava, or the Portrait of the Man. Today it is difficult to say how many portraits Sittow may have painted. The style 
and quality of some - for example the portrait of Henry VII (The National Gallery, London) - do not correspond to Sittow's work. ${ }^{66}$ New questions follow the old, resulting in new parallels and unexpected arguments. In addition to the works already established in the artist's gallery, I would like to present a few more examples that resemble Sittow's work for the consideration of future critical decision-makers. The first is the portrait of an unknown young man in half profile at the Art Museum "Riga Bourse" the similarity of which to the older gentleman in Hague apparently goes deeper than the stylistic considerations. Both - the Hague and Riga man - are portrayed in half profile. A concrete businesslike demeanour and a gaze directed outside the frame of the picture is characteristic of both portraits. The subjects have elongated faces, aristocratic noses and narrow, as well as, self-confidently pursed lips. The Riga man is younger, and perhaps more open. Both are dressed in the formality characteristic of the period. Dark, beret-like headwear partially hides the forehead and a lock of hair. In Riga, the man's long reddish hair falls to his shoulders. The shoulders of both men are covered by wide collars that were the fashion of the day. Against the reddish coat, a white shirt neck and skin-tone neck are visible. In portrait in The Hague, the painting's background is a darkish blue-green; in the Riga painting, it is lighter - more of a shading. ${ }^{67}$ The chest of the Riga man is decorated with a carnation (or pink) - a motif we also find in the Portrait of a Man with a Pink (The J. Paul Getty Museum) that is included among Sittow's portraits.

The portraits that Weniger has identified as being painted by Sittow also includes the Young Man with a Red Hat (Detroit Institute of Arts), which has sometimes been considered to be Sittow's self-portrait. However, the person on the painting is too young and in this way does not correspond to the type of portraiture that was considered to be characteristic of the artist's mature years. Instead of this we can find the similarity in between the "Artist's self-portrait" mentioned above two portraits of Anthony of Burgundy, the illegitimate son of Philipp the Good - one in Dresden (Staatliche Kunstsammlungen Dresden) and the other in Chantilly (Musée Condé). D. de Vos associates the former with

66 The author of the article has pointed this out some years ago. See: Juhan Maiste "Lübecki linnas Tallinnas", Kunstiteaduslikke Uurimusi, 16 (1-2) (2007), 192.

67 The undersigned does not know of any technical analysis having been conducted on the Riga painting, which could result in a reassessment of the initial shades of colour. 
Memling and the latter with François Roger de Gaignières. ${ }^{68}$ However, the candidacy of Michel Sittow is also conceivable. In all, this provides another reason to speak about both the ideals and predominant canon that had been accepted by such a wide international circle.

Thus Sittow belongs to an innovative group, in which, along with the Netherlandish artists, a mark was left by the great masters of the Italian quattrocentro - from Botticelli to Leonardo and Antonello da Messina to Pinturicchio (cf. Antonello's Retrato de un hombre, 1475-1476, Museo Thyssen-Bornemisza). Along with the luxuriously refined attire, the facial expression - the eyebrows, eyes, eyelids, nose and lips - the subject speaks a language that usually does not allude to anything but one and the same artistic idea and the skill to play along in an opera created by the various artists and various brushes, where distinguishing one genius from another is not only complicated but often impossible. The pair of concepts - the genius and his myth - live side by side, thereby periodically giving birth to new ideas, and bringing pictures out of yet to be opened treasuries and expressing thoughts about them that cannot be prohibited by the most authoritative orders. Little has been written about Sittow's followers or pupils. In this respect I would like to end this chapter with the small surprise from recent exhibition in the Tallinn Town Hall, where a male portrait similar to Don Diego de Guevara, is wearing a coat with a wide ermine collar, with a white shirt neck peeking out from underneath. A hand with long sensitive fingers is lying on a luxurious folio volume. But inspite of all this - the author of the portrait is far from Sittow's level. Today it is difficult to say whether this is an exercise by one of Sittow's students, a product of his workshop, or even a copy of one of Sittow's still unknown paintings. ${ }^{69}$

\section{SITTOW AND LOCAL COLOUR OF TALLINN}

Sittow was born and died in Tallinn. Starting with Johansen and Sten Karling ${ }^{70}$, many other works in Tallinn have been attributed to Sittow, including Johann Balliw's gravestone and the wooden sculpture of St.

68 De Vos, Hans Memling: The Complete Works, 342.

69 The undersigned thanks Adrian Melnikov for allowing the use photos of the portraits at the exhibition at the Tallinn Town Hall.

70 Sten Karling, Medeltida träskulptur i Estland (Stockholm: Kunglige Vitterhets Historie och Antikvitets Akademien, 1946), 64. 
George (both in St. Nicholas' Church). However these are purely stylistic parallels; what thanks to Matthias Weniger, are crossed out from the list of the artist. ${ }^{71}$ What still remains on the list is the altar of Christ's Passion (St. Anthony's altar) in Tallinn's St. Nicholas' Church, which was the first associated with the Sittow name by Johansen. Among art historians, the topic of the overpainting on the outer wings of the altar of Christ's Passion has repeatedly provoked controversy, inspiring Mai Lumiste to write the following: "The general composition remained the same, but the figures were updated. The monk (St. Francis) on the left panel became St. James (James the Elder) and the nun (Antonius from Padua) became the Virgin Mary with Child; on the right panel, the bishop (Bonaventura) was replaced by a knight (St. Adrian) and the monk (Bernhardinus from Siena) by St. Anthony. ${ }^{72}$ The bottom layer of painted was not scraped off, it remained as a thin but well-preserved layer under the overpainting. In the faces of the knight and St. Anthony, we can clearly discern Sittow's cool intellectual style, his confident and precise modelling. Based on psychological interpretation and type, these heads fit will with Sittow's confident portraits. It is possible that actual individuals are depicted (especially in the case of the knight) because it was Sittow's custom to portray saints in a manner related to portraiture."73 Weniger adopts the idea presented by Lumiste. However the undersigned still dares to doubt it. To my mind the artistic level simply does not correspond to a work produced by the mature Sittow. The same opinion has also been asserted by Helena Risthein: "Based on current information, it is difficult to associate the overpainting with the famous Flemish artist, Michel Sittow, who was born and died in Tallinn ... The participation of Jürgen Dreiger, the Tallinn master who died in 1519, and was influenced by Sittow also cannot be proven." ${ }^{\prime 7}$ Thereby bringing the discussion back to one of the first cornerstones of the Sittow myth.

The world presented by the artist - the "beautiful foreign faces" which were in demand in the provinces were a part of a wide-ranging

71 Weniger, Sittow, Morros, Juan de Flandes. Drei maler aus dem Norden am Hof Isabellas von Kastilien, 105. These works have not been included among Sittow's works in the chapter on Sittow in Eesti kunsti ajalugu 2. 1520-1770 (see: Maiste, „Michel Sittow - Tallinna mees“, 15 ff).

72 The saints are identified according to Matthias Weniger. See: Weniger, Sittow, Morros, Juan de Flandes. Drei maler aus dem Norden am Hof Isabellas von Kastilien,, 97-98.

73 Mai Lumiste, "Antoniuse altari algsest maalikihist ja ülemaalingutest", Kunst, 2 (1964), 34-35.

74 Helena Risthein, „Kannatusaltarist ja frantsiskaanlusest. Altaritiibade välisküljed enne ülemaalimist", Eesti kunstisidemed Madalmaadega 15.-17. sajandil, 89. 
cultural project that encompassed Northern Europe from the Baltics to Scandinavia, and which provided painting a distinguished place in the era's spiritual code and the exposition of the social relations that accompanied it. And bestowed dignity on people, which as Panofsky writes, "... raised the individual psychological ego in the context of a small world" 75 providing a possibility, in the form of an artistic image, to speak simultaneously about the natural and supernatural, and to deal with it in the idiom of both realism and idealism. ${ }^{76}$

Sittow's paintings are multi-layered - iridescently azure and alluring for the Hanseatic citizens of the day, echoing the search for a new worldview, which on the religious plane emphasised a personal connection with the highest power. And as such won an audience for the artist. Sittow pushed open the gate that already allowed Bernt Notke to employ Netherlandish poses and elegantly sparkling colours when painting Tallinn's Dance of Death. Sittow took a further step, by stepping from the "Autumn of the Middle Ages" to the "Spring of the Renaissance"77, and thereby enabling Max Friedländer, already in 1915, to speak in Sittow's case of something that was foreign to the Netherlandish tradition." ${ }^{178}$ In Sittow's art we find something that is lacking in both Hugo van der Goes and Hans Memling, and for which Robert Rebas has described as "Revaler Lokalkolorit."

\section{THE BLACK HEADS CONFRATERNITY'S ALTAR OF THE VIRGIN MARY IN TALLINN}

Along with Hermen Rode's main altar and the altar of Christ's Passion north of it, the altar of the Virgin Mary, also known as the Black Head's altar, is one of the masterpieces from the late $15^{\text {th }}$ and early $16^{\text {th }}$ centuries in the Niguliste Museum (St. Nicholas church) in Tallinn. As an opus magna - one of the most prominent altarpieces in the Baltic world it il-

75 Panofsky, Die altniederländische Malerei. Ihr Ursprung und Wesen, 16.

76 Dirk de Vos, Flämische Meister: Jan van Eyck, Rogier van der Weyden, Hans Memling (Köln: DuMont Verlag, 2002), 9.

77 Juhan Maiste, „Die Renaissance in Tallinn. Ein neuer „Stil“ in der alten Hansestadt“, Finskt Museum 1992, 99, ed. by. Marianne Schauman-Lönnqvist (Helsingfors: Finska fornminnesföreningen, 1994), $28 \mathrm{ff}$.

78 Friedländer, "Ein neu erworbenes Madonnenbild im Kaiser-Friedrich-Museum, 177.

79 Robert Rebas, "Der Maler Michel Sittow", Beiträge zur Geschichte der Baltischen Kunst", ed. by Erich Böckler (Giessen: W. Schmitz Verlag, 1988), 211 ff. 
lustrates the art consumption in the Hanseatic town and the cultural geography of the day, as well as clearly indicating a change in art orientation - the increasing role of the new art centres in the Low Countries and acceptance of the new ideas by the town's citizens. Unfortunately today we do not know who commissioned the altar, or when and where it was to be installed. Also unclear is when the altarpiece was produced and who made it, and this fact, just like in the case of the Passion altar, has prevented the issue of the altar's authorship from become the focus of attention, and thereby, at the very least, framing one of the key issues of Estonian art history until the present time. The discussion related to the authorship of the altarpiece is an important yardstick not only for the altar itself, but also in regard to Estonian art history more generally. What place in the art history narrative can be assigned to facts and what is that mythical subject matter that undertakes to interpret the gap between the known and the unknown when the facts are lacking?

In the broadest sense, there are two different positions in regard to the altar of the Virgin Mary: the first is associated with the opinion that emerged in the $19^{\text {th }}$ century that the altar was made in Bruges at Hans Memling's workshop, and the other is the popular $20^{\text {th }}$ century hypothesis that the altar originated from the workshop of the anonymous master in Bruges, known as the Master of the St. Lucy Legend. Both have their arguments, historiography and traditions. Neither of them has found support in the facts, thereby caused incisive arguments on the pages of the specialised literature and raising philosophical questions about whether the intuitive decisions of the past are better than the intuitive decisions of the present and how we should read art history in this mysterious reclusion $?^{80}$ Quo vadis art history?

The altar was elevated into factual historical knowledge by Gotthard von Hansen, who in his book dedicated to Tallinn's churches and cloisters that was published in 1885, connected it to the altarpiece for St. Catherine's Church in the Dominican Monastery commissioned from the "West" (Flanders) by the Tallinn Black Heads in 1495, and which arrived in the Hanseatic town via Lübeck. ${ }^{81}$ In connection with the history of the Tallinn Confraternity of Black Heads that was published in

80 Anu Mänd vs. Juhan Maiste. See: Anu Mänd, „Lucia legendi meister identifitseeritud?“, Juhan Maiste, „Lübecki linnas Tallinnas“, Kunstiteaduslikke Uurimusi, 16 (1-2) (2007), 173-200.

81 Gotthard von Hansen, Die Kirchen und ehemaligen Klöster Revals (Reval: Verlag von Franz Kluge, 1885), 60-61. 
the same year, the altarpiece was taken under closer examination by Friedrich Amelung ${ }^{82}$, who in one of his manuscript notes that the Black Heads commissioned the altar in 1493. Amelung was also the first to consider Hans Memling as the author of the altarpiece, and says that it was probably the last large-scale work the artist completed before his death in $1494 .{ }^{83}$

Amelung's opinion is supported by Riga architect Wilhelm Neumann, ${ }^{84}$ who a few years later still revised his opinion a few later and wrote: ", Den Meister der schönen Altars müssen wir im Kreise der Nachahmer des Hans Memling suchen, an den er sich augenscheinlich eng anlehn, ohne ihm jedoch in der Feinheit des seelischen Ausdrucks der Köpfe und in der Farbenharmonie zu erreichen. Anlehnungen an ihn finden sich in der Figur des heiligen Johannes auf der Mittelbilde mit der thronenden Maria des Johannesaltar im Spital zu Brügge, wie in den Bildern der äusseren Flügel und einigen Köpfen des Altars in der Greveraden-Kapelle zu Lübeck. ${ }^{485}$

Neumann's opinion is supported by Sten Karling, who writes: "Based on the style, the altar seems to have originated in Bruges ... and undoubtedly, those who believe the Black Heads' altar to be associated with Memling himself are right. However, just as correct is the observation that more than one person has participated in the execution of the work. The altar was produced in a workshop, and therefore, its execution is comparatively uneven. Some parts are downright brilliant, but next them, we see ones that are relatively poorly executed... The donors - a group of members from the Confraternity of Black Heads - are kneeling before the Virgin Mary and John the Baptist. Some of the portraits are wonderfully executed, and closely resemble Memling's penetrating human closeness that is borne by a warmth of heart. The rest, especially the Heavenly Father and Christ with angels, provide an inkling of the

82 Friedrich Amelung, Geschichte der Revaler Schwarzenhäupter (Reval: Wassermann, 1885), 5152; Wilhelm Neumann, Grundriss einer Geschichte der bildenden Künste und des Kunstgewerbes in Liv -, Est- und Kurland vom Ende des 12. bis Ausgang des 18. Jahrhunderts (Reval: Verlag von Franz Kluge, 1887), 103.

83 Friedrich Amelung, Die Memlingische Flügelaltargemälde in Revaler Schwarzhäupterhaus und deren Kunstsinniger Mitstifter der Revaler Grosskaufmann Hans Paulsen. 1906. Mss. in the Estonian History Museum, f. 237, n. 1, p. 241. At the of Eve the Reformation, the altar was brought from the Dominican Monastery for shelter to the House of the Black Heads.

84 Eugen von Nottbeck, Wilhelm Neumann, Geschichte und Kunstdenkmäler der Stadt Reval (Reval: Verlag von Franz Kluge, 1896), 206.

85 In 1909, when the arhitect restored the House of the Black Heads he wrote the opposite, that the two altars in Lübeck and Tallinn have nothing in common. Tallinn City Archives (TLA), f. 87, n. 1, s. 396. 
style of Memling's closest student from Bruges, the so-called "Master of the St. Lucy Legend". ${ }^{86}$

Thus, a new name had appeared on the stage - the Master of the St. Lucy Legend - to whom Mai Lumiste attributed the entire altar in 1961. Her opinion was also supported by Nicole Veronee-Verhaegen. ${ }^{87}$ Thus, a new myth had seen the light of day, which rejected all prior opinions, placed its bet on a master that was active in Bruges at the end of the $15^{\text {th }}$ century and produced the painting for St. James Church dated 1480 that depicts the legend of St. Lucy. In the foreword written on the occasion of $500^{\text {th }}$ anniversary of the arrival of the altar of the Virgin Mary in Tallinn, we can read the following: "M. Lumiste resolved the problem of the authorship of the Tallinn's Confraternity of Black Head's altar of the Virgin Mary." 88

With this opinion we could end the story. If questions did not arise regarding Mai Lumiste's positions that are hard to answer. It could even be said that the history of asking these questions dated back to the $19^{\text {th }}$ century. Unfortunately neither Hansen nor Amelung indicate exactly where they found their information. Despite her thorough searches in the relatively well-preserved archives of the Black Heads in Tallinn and Hamburg, Anu Mänd's has not been able to identify the sources in her writings. ${ }^{89}$ According to Mai Lumiste the altarpiece was already commissioned in $1481,^{90}$ which is in turn is refuted by A. Mänd, who says that the documents that Lumiste cites do not refer to an retable but a canvas or sheet that was commissioned for the relatively modest sum of 20 Riga marks, on which a scene of Christ's Passion was painted, and which was supposed to be placed on the altar of the Virgin Mary. Mänd also points out a totally different report in the archives of the Great Guild, according to which "in 1493, Alderman Gosachalk Remmelinkrade ordered a new 'panel' for the altar located 'with the monks' that arrived from the West via Lübeck and was intended for the Great Guild and the Black Heads. The transport of the altar cost 208 marks of which the

86 Sten Karling, Tallinn. Kunstiajalooline ülevaade (Tallinn: Kunst, 2006), 85.

87 Nicole Veronee-Verhaegen, „Un important retable du Maître de la Légende de sainte Lucie conservé à Tallinn“, Bulletin de l'Institut royal du Patrimoine artistique, IV, 1961, 142-154.

88 Mai Levin, "Sissejuhatuseks", Eesti kunstisidemed Madalmaadega 15.-17. sajandil, 5.

89 Anu Mänd, "Tallinna Mustpeade vennaskonna Maarja altarist ja selle ikonograafiast”, Eesti kunstisidemed Madalmaadega 15.-17. sajandil, $220 \mathrm{ff}$.

90 Mai Lumiste, „Lucia-legendi meistri teos Tallinnas. Mustpeade altari autori probleemist“, Kunst, 2 (1961), 32. 
guild paid half ... In addition, this would confirm that the altar was located in the Dominican's church." ${ }^{91}$

Based on provisional dendrological research, we know that the oak used to produce the altar dates back to the $1470 \mathrm{~s}$ to $1480 \mathrm{~s} .{ }^{92}$ However, who was the author? Or more precisely, in which workshop was it produced? As an artist, Hans Memling hardly needs any additional commentary. But who was the anonymous Bruges master who was christened the Master of the St. Lucy Legend by Max Friedländer. To whom he initially attributed three and then, some time later, another 18 works. This list has been further supplemented by both N. Verhaegen as D. de Vos and, in his $1982 \mathrm{PhD}$ thesis, by A. M. Roberts. Since then various attempts have been made to identify the Master of the St. Lucy Legend. However, despite this, the master and his entire body of work is still mostly fictitious, thereby inspiring ever new searches and a critical review of the current attributions in order "to restart the objective examination of the paintings one by one". ${ }^{93}$

The connections between the Master of the St. Lucy Legend and the altar of the Virgin Mary in Tallinn apparently need to be reread several more times. In her survey of Mai Lumiste's attributions in a recent article, Kerttu Palgimõmm points out some significant differences as well as several similarities between Tallinn's altar of the Virgin and the works attributed to the Master of the St. Lucy Legend, and writes: "Beim Revaler Retabel sind grosse Qualitätsschwankungen erkennbar und das nicht nur zwischen den Porträts der Stifter restlichen Gemälde. Es ist eindeutlich, dass am Werk mehrere unterschiedliche Meister oder Gesellen gearbeitet haben." In Palginõmm's opinion, the great fluctuations in quality may have re-

91 Mänd, "Püha Viktor - Tallinna kaitsepühak", 10-11.

92 Provisional dendrochronological examinations were conducted at the St. Nicholas' Museum within the framework of the Wood and Art workshop on 16 to 18 February 2015 and are based on the results of examinations by Dr. Aoife Daly. The measuring was conducted on the rear of the bevelled fifth plank of the altar's central panel using a non-destructive method, i.e. the tree rings were measured based on high-resolution photos. The felling of the tree was dated back to 1463; and the origin is Baltic oak (type: Baltic 1). The value of the results turned out to be surprisingly high $(t=9.01)$, which shows the high reliability of the data. In regard to dating, it is important to consider the seasoning period subsequent to the felling of the tree, which in the $16^{\text {th }}-17^{\text {th }}$ century was 2 to 8 years; in the $15^{\text {th }}$ century 10 to 15 years (Peter Klein, The Structural Conservation of Panel Paintings (Los Angeles: The Getty Conservation Institute, 1998), 44). However, this is the result obtained from the examination of one board of the altar's central panel, and in order to confirm or disprove it, the other boards should also be examined. Hilkka Hiiop's report to the author in June 2015.

93 The Flemish Primitives, IV. Masters with Provisional Names, 293. 
sulted from the division of labour within one workshop but also from "subcontracting" and hiring additional labour from other workshops. ${ }^{94}$

In my prior statements, I have repeatedly made clear my position that several different masters participated in the completion of the altar of the Virgin Mary. ${ }^{95}$ According to Karling, the style of the Master of the St. Lucy Legend can be distinguished only on some of the painting panels, of which as I stated many times before - Maria Lactans and Christ with Two Angels - can be really associated with the only work that can be obviously attributed to the Master of the St. Lucy Legend. First of all, this is evident in the figures of the angels with their elongated silhouettes and small heads comprising only one tenth of the bodies. The pallid faces of the angels lack any shades of emotion. However, the Tallinn angels differ from the Bruges angels when it comes to several important features. Thus, the eyelids of the Tallinn angels, which cover more than half of their pupils, differ from the ladies on the St. Lucy Legend altar. The figure of the Mother of God resembles the angels with her half-closed eyes and her long-fingered hand indicating her guardianship of the group of 15 men kneeling before her.

The fifteen figures depicted in front of John the Baptist merit our attention. Who were these gentlemen who were able to commission an expensive altar?96 Along with the other fifteen gentlemen depicted on

94 Kerttu Palginõmm, „Mai Lumiste und der Problemkreis des Schaffens des Meisters der Lucialegende“, Kunstiteaduslikke Uurimusi, 2013, 22 (3-4) 2013, 73.

95 Maiste, „Die Renaissance in Tallinn. Ein neuer „Stil“ in der alten Hansestadt“; Maiste, „Michel Sittow - Tallinna mees“; Maiste, „Perception of Beauty in Late Gothic and Early Renaissance Art in Tallinn. From the Dance of Death to the Rebirth of an Image“, Tuldud teed edasi. Along the Trodden Path (Tallinn: J. Maiste, 2007), $59 \mathrm{ff}$.

96 As pointed out by Fr. Amelung the intermediary for the commission was Lübeck merchant Hans Pawels, who had bought a house in Tallinn in 1494 and quickly rose to be a member of the town's elite. (Rasmus Kangropool, Tallinna hilisgooti etikukividest Vana Tallinn IV (VIII) (Tallinn: Estopol, 1994), 7.) Twenty years later, Hans Pawels signed a contract with the master, Bernt Wolte, for the construction of the chapel of the Virgin Mary in St. Olaf's Church. His cenotaph on the eastern wall of the chapel was completed in the same year. (Sten Karling, „Die Marienkapelle and der Olaikirche in Tallinn und ihr Bildwerk", Ein Beitrag zur Brabenderfrage. Publicationes de Cabinet d'historie de l'art del'universite de Tartu, I, 1937, $11 \mathrm{ff}$.) Quite an interesting parallel is provided by another person named Hans Pawels, about whom information exists from Lübeck dating from 1469 to 1487 (information from Prof. Uwe Albrecht 2006). He may have been, but not necessarily, a relative of the aforementioned Pawels (or even the same person). According to Ludwig Kämmerer, Pawels, along with Heinrich Greverade and Heinrich Castorp, was one of the founding members of the Confraternity of the Sacred Cross and builders of the Chapel of the Sacred Cross of Our Lady's Church (completed in 1493), for which a large altar of Christ's Passion was commissioned. (Ludwig Kämmerer, Memling (Bielefeld, Leipzig: Velhagen \& Klasing, 1899), 130.) Today, this opinion has been refuted, and instead, "a fairly spectacular theory that on the altar there are depicted three great German painters: Michael Wolgemut, the young Dürer and Memling" has been presented. (De Vos, Hans Memling: The Complete Works, 326.) 
the opposite wing of the altar, they are thought to be members of the Great Guild and the Tallinn Confraternity of Black Heads. And this is extremely probable. Whereas a question is raised by the very different levels of artistic quality of these figures. The two figures in the front row of both wings are clearly painted by another, much more experienced and talented hand. The style of painting that can be observed in the figure of John the Baptist is also different. A man of flesh and blood, with an expressive face and credibly realistically portrayed coat, he finds his closest stylistic contact with Memling's figures.

To who in Bruges could the Tallinn men have turned? It is logical to assume that it was Hans Memling, who speaking the same language and sharing the same ideas, immediately understood the visitors from afar. Moreover, a large winged altar has just been completed, or was about to be completed, in Memling's workshop that was to decorate Lübeck, the Hanseatic capital. However, it was, unfortunately, not installed in the Cathedral until 1504, that is, ten years after Memling's death. Why? There is no unequivocal answer. According to Max Hasse, the work was completed during complicated times: "Der Bischof Albert Krummedick (who commissioned Bernt Notke triumphal cross - J. M.) hatte bei Seine Tode 1489 dem Domkapitel eine ungeheure Schuldenlast hinterlassen. ... Als um die Jahrhunderwende zuerst Heinrich Greverade und dann auch sein Bruder Adolf starben, wurde aus dem Nachlass Adolfs die Vicarie am Dom eingerichtet." ${ }^{\prime \prime 7}$ Based on the position of Dirk Vos, Uwe Albrecht presents another opinion and writes: "Vor 1504 scheint das Retabel noch nicht in Lübeck gewesen zu sein, vielleicht nach dem Tode Hans Memlings vorübergehend in Brügge benutzten Kirche des Karmelitenklosters aufgestellt." 98

What has kept the undersigned interested in this topic for years are the many era-related and artistic similarities between the two altars under discussion - Lübeck's so-called "Greverade altar" and Tallinn's so-called "Black Heads' altar". Beside Memling it is also possible to distinguish

97 Max Hasse, Hans Memlings Lübecker Passionsaltar (Lübeck: Museum für Kunst und Kulturgeschichte, 1994; Nachdruck von 1967), 5. Based on the Lübeck archives, Uwe Albrecht points out the fact that: "Am 30 April 1504 auf Antrags des Neffen und Testamentsvollstreckers Heinrich Greverade und dreier anderer Lübecker Bürger, Hermann Papenbrock, Moritz Loff und und Gottherd Wiggerinck." Unfortunately, this altar is not the referred to in the given records, rather a reference is made to Dietrich Grebbin, a member of the cathedral capital. See: Uwe Albrecht, Corpus der Mittelalterlichen Holzskulptur und Tafelmalerei in Schleswig-Holstein, Bd. I, Hansestadt Lübeck, St. Annen-Museum (Kiel: Verlag Ludwig, 2005), 261.

98 Uwe Albrecht, Corpus der Mittelalterlichen Holzskulptur und Tafelmalerei in Schleswig-Holstein, 261. 


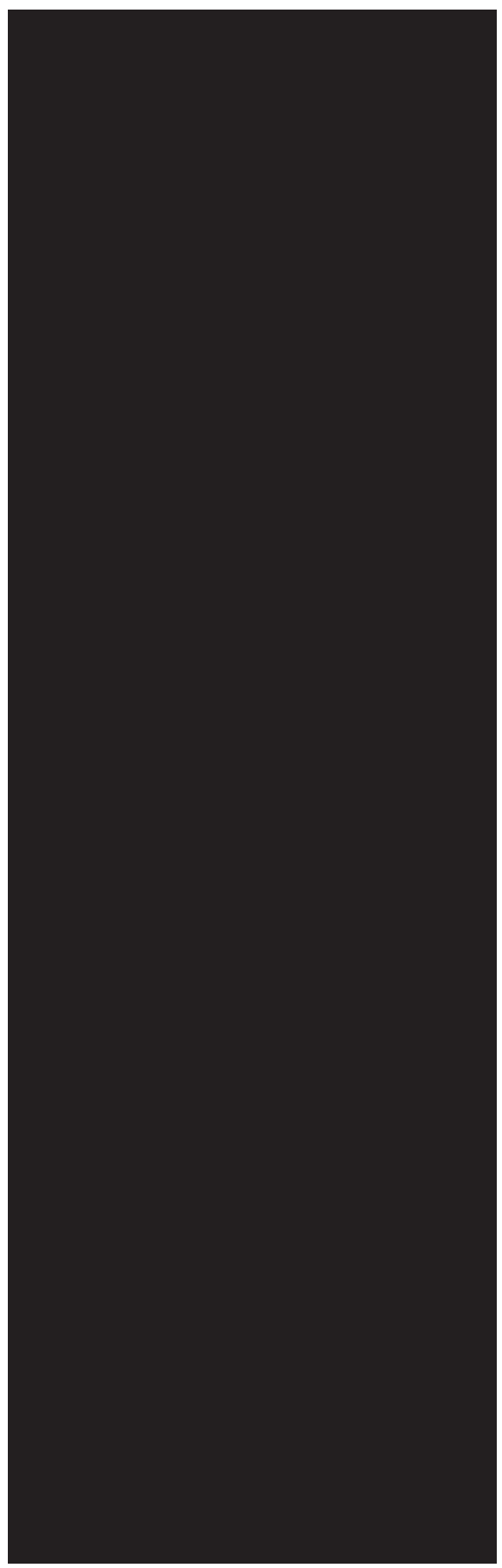

the hand of his various assistants. As suggested by De Vos, the grisaille panels with the figures of Archangel Gabriel and the Virgin Mary are poorer in quality and were not added until after $1500 .{ }^{99}$ In the broadest sense, the grisaille paintings on the altar's outer wings belong to the rhetorical repertoire of the era marking everyday life, which have been known since the times of Jan van Eyck (for example, the grisaille Annunciation-themed paintings on Jan van Eyck's Dresden Altarpiece, 1437, Staatliche Kunstsammlungen Dresden). Another example is the Triptych of the Burning Bush (Cathedral, Aix en Provence) by Nicolas Froment, which, based on its artistic credo, is very similar to the "Black Heads' altar" in Tallinn.

An even more direct link also connects Lübeck's and Tallinn's grisaille compositions. The sculptural presentation of the figures stand out in both cases. The figures seem to step out from the architectonic niches behind them. Both the poses and physiques are similar. But some differences can be found in the motifs.

99 De Vos, Hans Memling: The Complete Works, 326.

Fig. 1-2. Altar of the Virgin Mary of the Confraternity of Black Heads. In St. Nicholas church (Niguliste Museum) in Tallinn. Outer wings. Annunciation. Photo: Stanislav Stepaško. 
The archangel on the Greverade altar has a staff in his left hand; the Virgin Mary holds a book in her right hand, a dove is depicted above her head and a lily blossom in a brownish oil can be seen at her feet. Instead of a staff, Gabriel in Tallinn is holding a lily blossom in his left hand. The Virgin Mary has a book not in her right but in her left hand. Despite a few differences in the details, the general posture and gesticulation, as well as the drapery falling from their slender bodies (including the sharp toe of Mary's right shoe peeking out from under the draped dress), are similar. Although the scene on the Annunciation of the Virgin Mary in Lübeck is executed with more masterly hand and clearer contours, one cannot deny that they originated from the same workshop or that the composition in Tallinn is based on the Lübeck example.

Almost all the authors have directed attention to the German influence in the work of the Lübeck altar. Double winged altarpieces were common in Germany, but very rarely in the Low Countries", states D. de Vos. ${ }^{100}$ In the case of Tallinn, the

100 De Vos, Hans Memling: The Complete Works, 90.

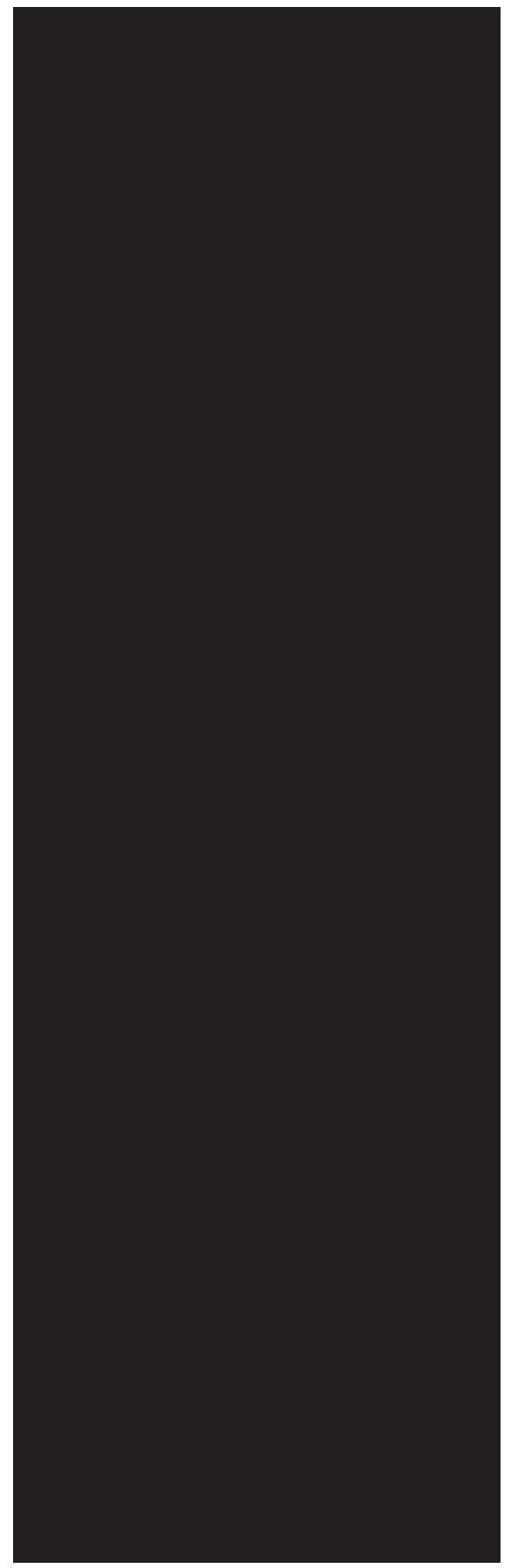




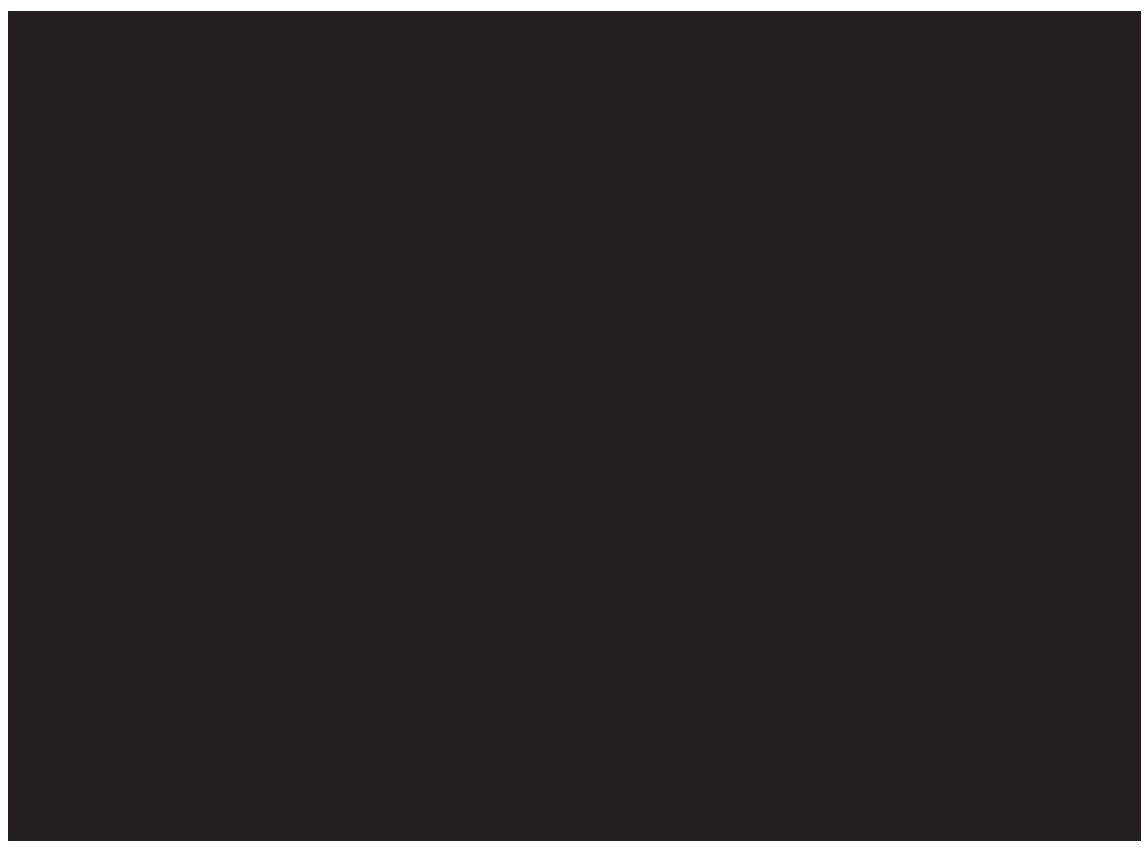

Fig. 3. Altar of the Virgin Mary in Tallinn's St. Nicholas' Church. Central panel: Virgin and Child Enthroned with St. George and St. Victor. Right wing: St. Francis. Left wing: St. Gertrude. In St. Nicholas church (Niguliste Museum) in Tallinn. Photo: Stanislav Stepaško.

local distinctiveness, i.e. local colour, cannot be ignored. This has been discussed above and the amber prayer beads held by a young prayer dressed in green kneeling before John the Baptist are an example of this. ${ }^{101}$ Just like in the rest of the Nordic countries, the Renaissance and its idiom of form played a decorative role, and its main goal was to satisfy the representational needs of the local merchants in Tallinn; new art was imported into the Hanseatic town as a luxury item. ${ }^{102}$ And there is one more interesting aspect. As Kerttu Palginõmm states that a greater than usual respect for books radiates from the painting, which may be explained by the fact that it was commissioned for Tallinn's Dominican Monastery, which was renowned for its library and general intellectual mentality. Books as paraphernalia are depicted on five occasions: "in der Hand von Franziskus, von Johannes dem Täufer, der Mutter Gottes, von

101 Ravo Reidna, Tallinna Mustpeade vennaskonna Maarja altar (Tallinn: Eesti Kunstimuuseum, 1995), 4.

102 See: Maiste, „Die Renaissance in Tallinn. Ein neuer „Stil“ in der alten Hansestadt“. 


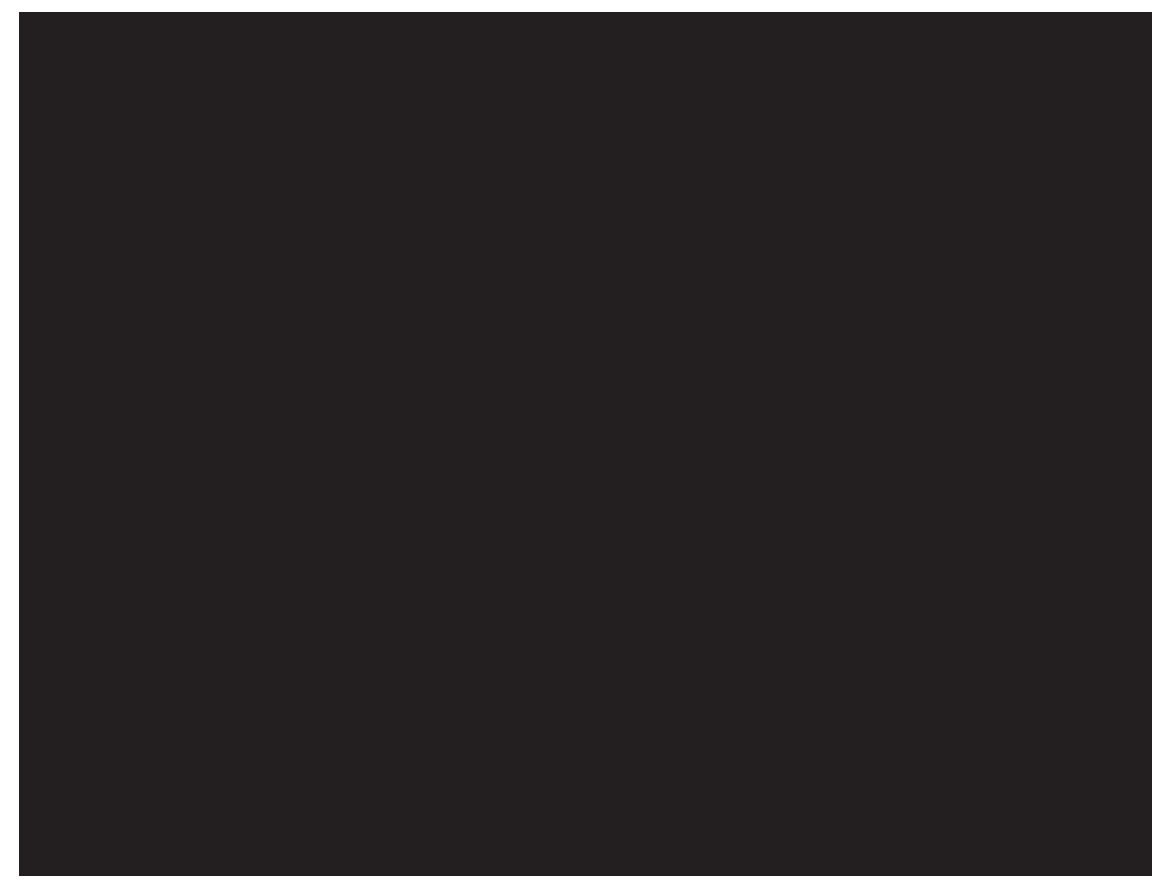

Fig. 4. Altar of the Virgin Mary in Tallinn's St. Nicholas' Church. Second position. The patronage scene with God the Father, the Holy Spirit, Christ, the Virgin Mary, John the Baptist and the kneeling donors. In St. Nicholas church (Niguliste Museum) in Tallinn. Photo: Stanislav Stepaško.

Gertrud und auf ihrem Äbtissinnenstab in der Hand, des als eine Skulptur dargestellten Johannes des Täufers noch ein zweites Mal."103

In comparison to most of the other altar compositions of the day, Tallinn's altarpiece stands out also for another reason. Namely, on seven of the panels, the background is brocade wallpaper, which, as a luxury item, was popular on the altars in the Low Countries, but which always left space for panoramas depicting nature, city views, the blue sky and the landscape stretching into the distance. In Tallinn, such a window looking out into the distance is missing, which raises a question about whether we are partly dealing with an older altar, the individual panels of which have been put together to create a new piece. ${ }^{104}$ Another reason to the somewhat unusual composition can be explained with the func-

103 Kerttu Palginõmm, "Luxusartikel auf dem Revaler Retabel des Meisters der Lucialegende als eine Einladung in die Stadt Brügge“, Baltic Journal of Art History, Autumn 2011/Spring 2012 (2011), 111. 104 Maiste, „Die Renaissance in Tallinn. Ein neuer „Stil“ in der alten Hansestadt“, 25. 
tion and position of the altarpiece in the church, which demanded the demonstration of the wealth of the local merchantry.

What can be said in summary? Certainly the altarpiece of St. Mary is a true example of the artistic idiom that was legitimatised in BurgundianFlemish art already in the first half of the $15^{\text {th }}$ century, recalling with its pompous central panel on Jan van Eyck's Joris van der Paele altarpiece. Mary's stoic figure with a luxurious fabric falling like a canopy, the light facial plane distinct from the dark background, the long golden locks falling onto her shoulders, and the half-turned figure of the totally elated Infant Jesus on the Virgin's lap, are motifs that appear time and again in Memling's large-scale compositions like the Altarpiece of Saint John the Baptist and Saint John the Evangelist (1474-1479; Bruges; Saint John's Hospital), Virgin and Child Enthroned with Saints Catherine and Barbara and Two Musical Angels (Metropolitan Museum of Art, New York), Triptych of John Donne (The National Gallery, London) as well as in the Lucca Madonna (Städelsches Kunstinstitut, Frankfurt). Also, most of the other figures participating in the formal ceremony can be treated as cut-outs from an album of heavenly rulers and saints that had become canonical in the $15^{\text {th }}$ century - be it the Holy Father, whose solid figure lives on in a tradition was already used by Bernt Notke (can be also vice versa: Notke used the Netherlandish patterns) and which was softened in Memling's work, by replacing its dignified majesty with psychological introspection. John the Baptist is also a Memling type, whose sensitive physiognomy resounds in Memling's compositions that are borne by religious devotion (incl. the Greverade altar). Two of the angel figures also allude to Memling's workshop and the work of the Master of the St. Lucy Legend, which was closely related thereto, and about which, D. de Vos writes that it "echoes the innovative approach of Jan van Eyck". ${ }^{105}$

Tallinn's altar is an example of the way in which pictures were composed in the "art factories" - one master might paint the saints' faces, another would paint the clouds, a third the brocade patterns, and the fourth the fabric folds. That is how it was outside of Italy in the $15^{\text {th }}$ century. Distinguishing a specific talent (master) among the others, will usually stay conditional. The leading master struck an agreement, agreed on the "programme," marked the main elements onto the panels and then handed out the assignments. Whereas there is no reason to

105 De Vos, Hans Memling: The Complete Works, 289. 
doubt that Tallinn's altar of the Virgin Mary was produced in one workshop. The same parquet pattern appears in almost all the altar panels. Forthcoming technical research will hopefully bring additional clarification to this question. ${ }^{106}$

Thus, we can speak about three possible handwritings in connection with these paintings ${ }^{107}$, of which one is associated with the central composition of the painting, and the supporting figures on the inner side. The second handwriting appears on the figures of the two angels and the kneeling Christ, what compared to the main portion of the painting can be described as more pale and schematic. The third handwriting is of better quality than the first two. Clearly a very important qualification must be mentioned at this point - some of figures of the well - dressed figures kneeling in front of St. John and St. Mary are painted with a quality that requires totally different skills and talent. It is possible that the gentlemen are portrayed as being somewhat younger and handsomer.

Whereas, Hans Memling's portrait of John Donne can be brought as a parallel for the older man on the left, whose thinning lock of forehead hair and slightly resigned expression are not quite as expressive in the Tallinn work, but in comparison still very telling - it is possible that the initial beauty has been diminished somewhat by subsequent restoration, the traces of which can be found in abundance on other parts of the altar. In the case of the refined sensitive younger gentleman on the right, we recognise a means of depiction that is revealed in many of Memling's best portraits: for example the portrait of the kneeling donor from the central panel of Virgin and Child Enthroned with Saint George (ca. 1480-1485; The National Gallery, London).

Memling's successor in the field of portraiture was Michel Sittow, whose abilities - as we can gather from the information presently above - are apparent in the unique psychological realism comparable to Dürer or then Rembrandt hundred years later. In the late 1480s or early 1490s, when the altar was commissioned, Sittow as not yet at the peak of his abilities, but they were sufficient to help the old master complete one of

106 In the light of the current data, the underdrawing of the painting was executed with a watery medium and quite minimally. A more intensive shading of the folds and individual pentimenti have been identified in the underdrawing. The element analysis identified a use of pigments and painting materials that were classic for this period. However, further systematic technical analysis of the altar and the development of comparative materials within a circle of possible authors would be justified. Hilkka Hiiop's reports to the author in June 2015.

107 Maiste, „Die Renaissance in Tallinn. Ein neuer „Stil“ in der alten Hansestadt“, 33 ff. 
his last great commissions. In the 1480s, when the altar was probably commissioned, there was simply no one else besides Memling of Bruges to turn to for its execution. My opinion is, that Michel Sittow in particular may have been the intermediary between the people from Tallinn and the Bruges workshop. "Wer damals in Brügge nach dem hervorragendsten Maler fragte, gelangte zu Memling", has once stated Max Hasse. ${ }^{108}$

Sittow's role in the completion of the altar would be a completely logical conclusion, a hypotheses that could be supported, or should at least be discussed, amongst the many other hypotheses. I agree with Michail Libman, who raised the idea of Sittow's authorship several decades ago. ${ }^{109}$ And this does not preclude that which Weniger has written: „Die Abweichung bei dem sehr eindrucksvollen Kopf der vordersten Schwarzehauptes auf Marientafel lassen sich allein aus dem Position im Altarganzen sowie insbesondere der Verwendung einer Naturstudie erklären. Allengalls könnte man eine größere Nähe zu Memling postulieren. Nichts weist über diesen hinaus auf Sittow. ${ }^{.110}$

The third master who participated in the completion of Tallinn's altar of the Virgin Mary was evidently the Master of the St. Lucy Legend.

\section{THE BIRTH OF A NEW MYTH}

When Karling wrote about the Black Heads' altar in 1937 he did not mention Sittow's name. And this simply because at that time Johansen had not yet discovered the Tallinn origins of the artist named Sittow. And Dirk de Vos had not written his following prophetic statement: "it seems that Memling and the Master of the St. Lucy Legend may have used the same workshop." 111 The undersigned believes that all three Memling, Sittow and the Master of the St. Lucy Legend - fit on the same map of the world. Just like a glove fits a hand on a crisp winter morning in Tallinn behind St. Nicholas' Church. I hope that none of them - truly good friends and colleagues at the end of the glorious $15^{\text {th }}$ century in Bruges - will rise from the grave upon such an opinion. In the words of

\footnotetext{
108 Hasse, Hans Memlings Lübecker Passionsaltar, 7.

109 Michail Libman, "Michael Sittow, Burgher of Tallinn and Court Painter of Queen Isabella of Castile (Additions and Specifications)", Actas del XXIII Congreso Internacional de Historia del Arte: España entre el Mediterráneo y el Atlántico, Granada 1973, 2 (1977), 339 ff.

110 Weniger, Sittow, Morros, Juan de Flandes. Drei maler aus dem Norden am Hof Isabellas von Kastilien, 118.

111 De Vos, Hans Memling: The Complete Works, 394.
} 
Villem Raam, the Estonian ars historica pater patriae, "Art history is the correction of mistakes, and first of all, the correction of one's own mistakes". As Søren Kierkegaard has stated "we are born to be ourselves" and therefore, we should not be afraid to be ourselves. If even 100,000 people are of the same opinion, then the sum of those opinions is still only one. Only when someone comes who has another opinion is the sum two. I believe that Michel Sittow is interesting for us because he was the "one". 
Juhan Maiste: A Genius and His Myth: The Known and UnKnown Michel Sittow

Keywords: Genius; Myth; Art Writing; Ars Nova; Michel SitTow

\section{SUMMARY:}

This article focuses on two problems - the first is connected to the methodological side of art writing and the philosophical background thereof, and the second to the work of Michel Sittow, an artist who was born and died in Tallinn, and was court artist to Isabel of Castile and several other grand courts. The author's point of departure is provided by a pair of concepts - the genius and the myth that has been composed about him. On the one hand, the latter becomes a means of expression for the artist's subjective will, which is often difficult to put in words, and on the other, provides a period-related and verbal context to surround him. One of the expressions of this context is art history, along with its possibilities, methods and traditions. Since Giorgio Vasari, art history has been accompanied by a longing for a single great narrative. This has often been attacked within the framework of $20^{\text {th }}$ century analytical philosophy and a deconstructive approach to myth has been given priority over a myth-creating approach, which science has labelled as speculative and romantic. Under the cover of exposing the myth of the artist, those doing the exposing often do not recognise their subconscious yearning to create new narratives and new myths. The increasing attention that Sittow and his work have started to receive in recent years provides some of the most telling evidence of this way of thinking.

In this essay-type article, the author pays tribute Sittow, Morros, Juan de Flandes. Drei maler aus dem Norden am Hof Isabellas von Kastilien (Kiel: Verlag Ludwig, 2011), a monograph by Matthias Weniger published in 2011. However, in addition to the path of reasoning presented by Weniger, the author also presents another approach, which along with and instead of the formal analysis of the works of one of the Renaissance-era geniuses, focuses on the possible preconditions and sources for the development of the artist's talent. However, it is not the ambition of the undersigned to construct a complete picture but to set forth the connections between the artist's spiritual "ego" and the intellectual "ego" of those writing about his work, which thereby contributes to intuitively 
conceptualistic and cognitive rather than empirical knowledge. One of the reasons for this approach is clearly the rather limited range of enlightening facts, which have been analysed many times over by Weniger and several others (Max J. Friedländer, Paul Johansen, Jāzeps Trizna, Chiyo Ishikawa), and that have become the cornerstone of Sittowiana, and therefore do not need to be repeated here in detail.

When writing about the life and activities of an artist in his era, we are inevitably writing about ourselves and the positions that prevail in today's scientific discourse and provide our knowledge with both content and an unavoidably restrictive framework. A cornerstone of the author's approach is knowing that all knowledge is limited and has an imaginary (visionary) nature. And as such within the framework of phenomenological philosophy includes the opportunity to see behind the "visible"; and along with skills, style and social context, to deal with possible psychological and religious aspects, the subjectively contemplative nature of which science usually excludes - often because science cannot manage to describe them.

Repeating an eternal truth, a dominant source for all knowledge is a person's eyes, the role of which, even alongside the most accurate technical measurement tools (X-rays and pigment investigations), is timeless and essential. The best microscope can only expand the scope of the human eye, but not assume the role of decision maker, or operate outside the range of a person's senses. The information on the picture reaches us through the contact between the information carrier (artefact) and the recipient. Art as truth places a stake on fantasy, the criterion of which is language and its innately characteristic search for new corresponding verbal metaphors for the scope of a work's poetic imagery.

The equivalent of the picture is the word; using words, the scientist interprets the material that becomes known to him, and provides a reason, in addition to the work's revelational nature, to speak about the work's recurring appearance in the viewer's eyes and consciousness. And each one of us has our own conception and fantasy. Thus, it is also possible to view Sittow's work from different angles, by amplifying the common positions and neutralising others, using the limited facts that are known about the artist.

The undersigned wishes to provide a place for all the possible positions within the framework of art history - the special "tenderling" of the humanities - and on these pages. By providing an opportunity for 
the old positions to live on and for new opinions to be born, by gathering various theories and facts that do not preclude, but rather complement, each other into a hermeneutic circle ennobled by history that helps to expand and enrich our understanding of a topic called Michel Sittow and his body of work. The more colourful the dress worn by art history, the richer it is. The goal of the article's author is convince the reader of the inexhaustible depth of art history as a paradigm, which the diversity of themes and colours characteristic of art can, in our scientific approach, turn into new and many-sided knowledge, and thereby create an opportunity to bring images (pictures) to life and give them the chance to perform miracles once again.

By providing a survey of Sittow's body of work - as the undersigned sees and assesses it - the main task of the article to speak about the immeasurable along with the measurable. To speak about that indefinable something, which, when communicating with art, can help us not only find out or learn something, but to become someone. In order to understand Sittow, it is necessary to understand his place in the world where he acted among and alongside dozens and hundreds of colleagues, while carrying within him a calling for free and creative self-expression that, by exceeding the power of tradition and routine, gave birth to miracles - artistic miracles. In order to recognise a miracle, we have to open our eyes. And this especially under circumstances when other tools (both technical and literary) are currently inadequate or totally missing.

All knowledge has its limits. Thus, the theses about Sittow's work in this article are far from complete, but rather direct the reader to the start of a long and interesting journey, to lines to which all subsequent writers are invited to add their thoughts. And as such to a milestone on the road leading from the past to the future that will lead us to the answer for the most important question posed in the article - quo vadis art history? NB! Just as every work of art appears as something new to the viewer, so too all writings on the topic of art are new and interesting up to the point to where the reader is ready to accompany the writer. Today we know both a lot and a little about Sittow. Documental data about his work is scarce, just as it is for most of the other Netherlandish artists during this exceptional era. At a time when, alongside the Italian geniuses, Netherlandish artists emerged who, compared to their colleagues born south of the Alps, were motivated by totally different ideas and practices; who were still artisans as much as they represented the cre- 
ators of a new era in the world; and whose art meant succeeding in life and in a career in their profession. In order to research Sittow further we require even broader knowledge, which on the one hand, assumes new developments in scientific methods, and the expansion of the basis of laboratory research; and on the other, the utilisation of art history's secret weapon - intuition and a sharp eye - which can become of key importance in the instrumentarium. What I want to say in the broader sense is - trust your own vision and also take others into account.

CV:

Juhan Maiste is a professor and Head of the Department of Art History at the University of Tartu. As a prolific writer he has authored a large number of monographs and articles on architecture, classicism, cultural heritage, the philosophy and poetics of art history. His scholarly interests include Estonian and Livonian manor architecture, the phenomenon of park landscapes as well as the work of Johann Wilhelm Krause. In addition to teaching and research, Professor Maiste is the editor-in-chief of the Baltic Journal of Art History. 
